\title{
EGYPTIAN WESTERN DESERT DEVELOPMENT CORRIDOR: A CRITIQUE ANALYSIS AND A PROPOSED CONCEPT
}

\author{
Antar A. Abou-Korin \\ Ph.D. Minia Univ. \& Texas A\&M Univ. 1992; \\ Ph.D. Sheffield Hallam Univ. 2004
}

(Received June 13, 2011 Accepted July 26, 2011)

Since the seventies of the last century, debate over "Development Corridor" project, proposed by famed Egyptian geologist Dr. Farouk El$\mathrm{Baz}$, is mounting. Such debate has gained more momentum since the 25th of January Revolution in Egypt and reached the extent of proposing to start the financing phase through registering the project in the stock market. However, and because of the huge investments required for this project in this crucial stage that Egypt is going through, and in the light of the fact that many of similar projects implemented in Toshka, Abu-Tatur, East Owianat, have failed to achieve their development objectives, it is necessary to deeply and thoroughly examine the nature, objectives, feasibility, and the ability to implement his huge project.

This paper has two main objectives: first, is to present a subjective critique analysis for the project; second, is to find out rational answers for most of its drawbacks. In reaching its first objective, the paper presents in Part 2 a discussion of the points of agreement the paper shares with the project idea. In Part 3, the paper presents a critique analysis for the planning concept of the project regarding its idea, objectives, and components. In this regard, the research discusses the strategic impacts of the project and then examines its adherence to basic planning principles such as: rationality, balance between costs and rewards, and development priorities. Through these two parts, the paper comes to an important conclusion that the project in its current formulation does not abide to some necessary planning principles which makes it loses its rationality and feasibility for the country, especially in its delicate socio-economic and political conditions. In reaching its second objective, the paper proposes in Part 4 a modified planning concept for the project so as to overcome most of its drawbacks.

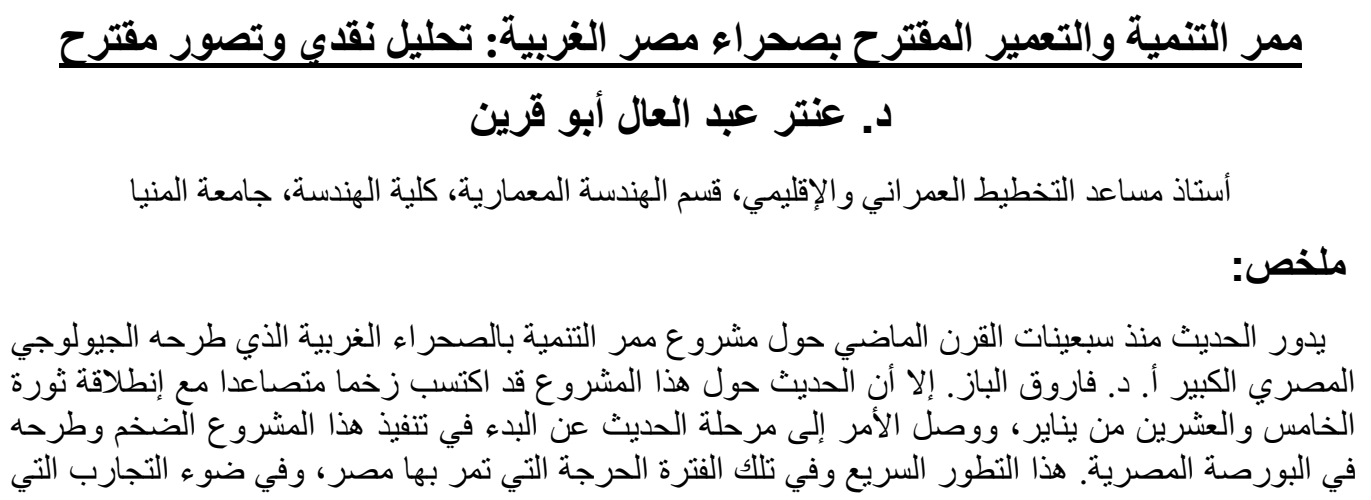


قامت بها مصر في توشكى وأبو طرطور وشرق العوينات، وما لحق باغلبها من فثل بدرجات متفاونة، بات من

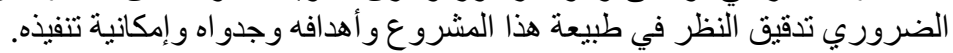

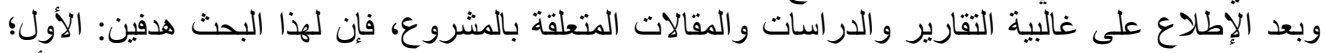

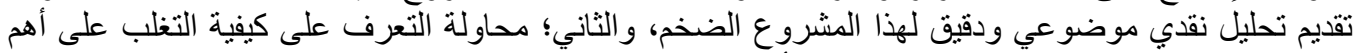

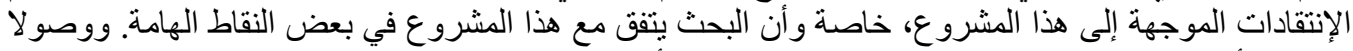

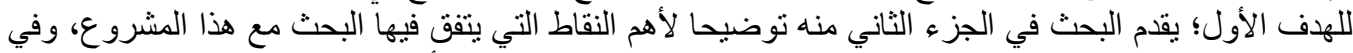

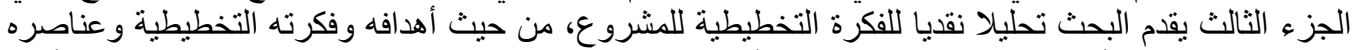

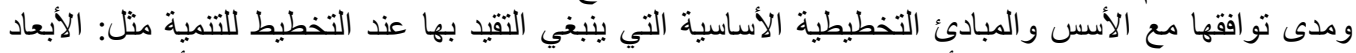

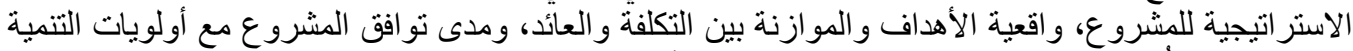

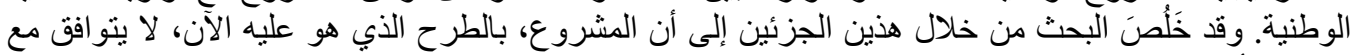

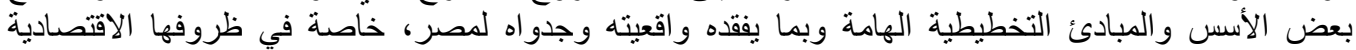

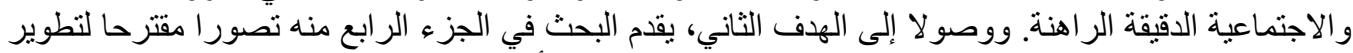

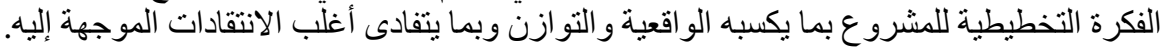

الكلمات الدالية: ممر التنمية والتعمير - الصحر اء الغربية ـ تنمية الصحر اء

مقدمة:

تتمية الصحر اء، هى ذللك الحلم الذي ير اود المصريين منذ عهد الفراعنة وحتى اليوم. إنه أمل وضرورة دوة، ولكنه

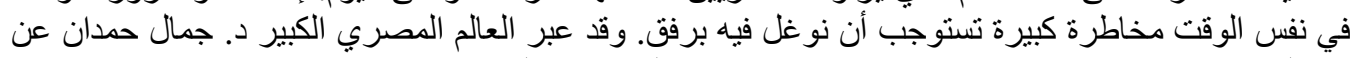

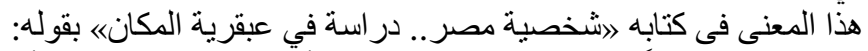

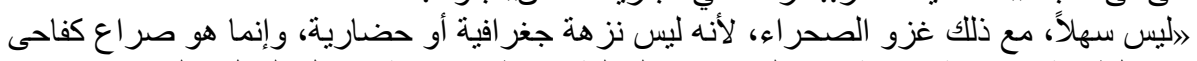

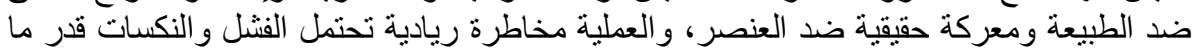

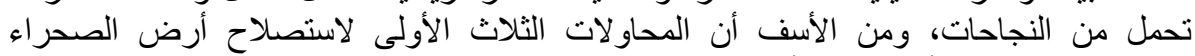

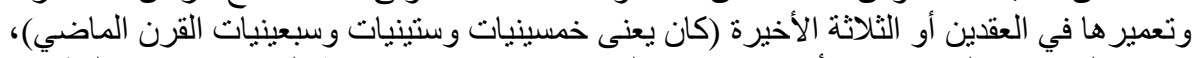

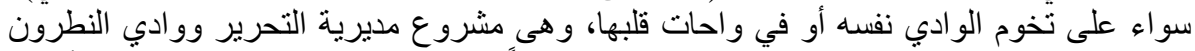

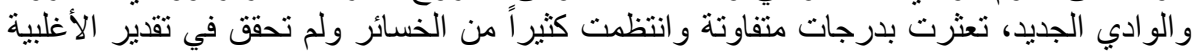

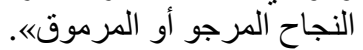

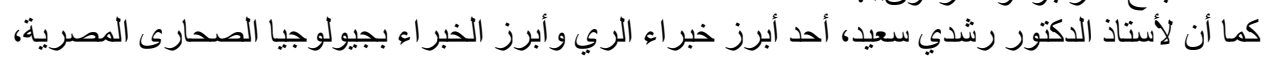

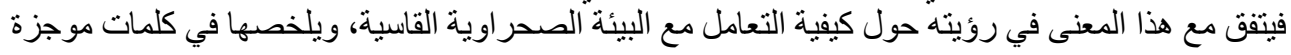

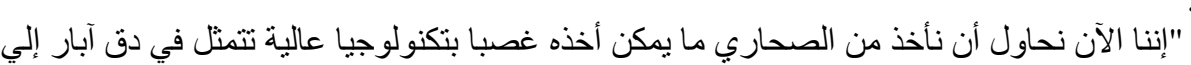

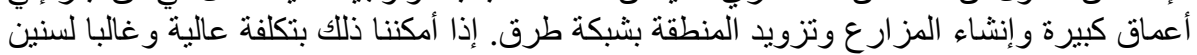

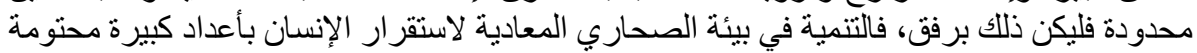

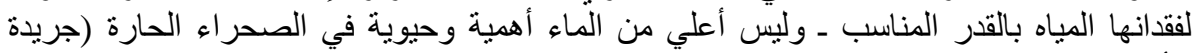

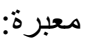
الأهر ام بتاريخ 17 يناير 2006).

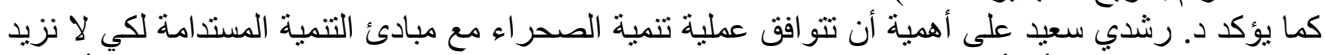

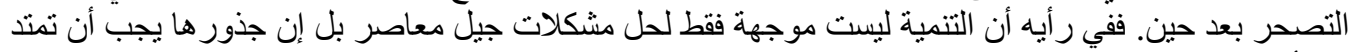

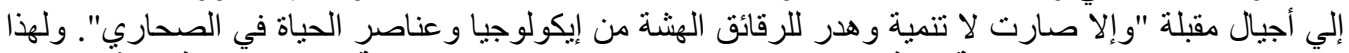

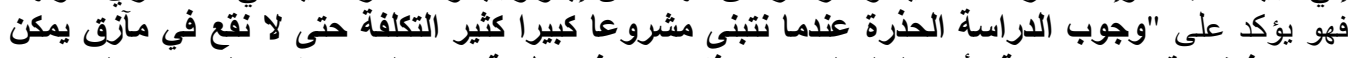

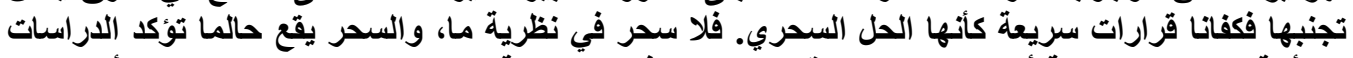

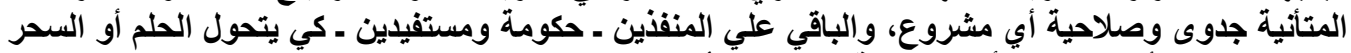

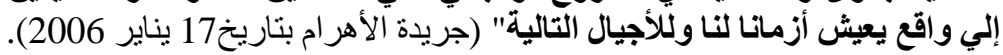

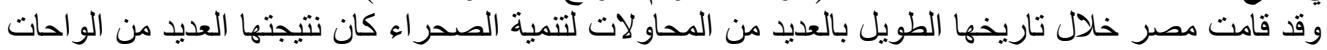

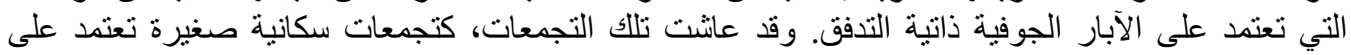

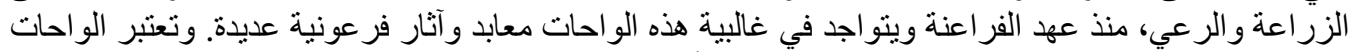

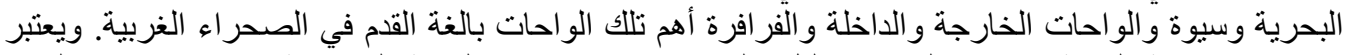
بقاء واستمرارية التنمية في هذه الواحات دليل على توافقها مع مبادئ التنمية المستدامة سواء الفية من حيث الحجم 
السكاني أو النشاط الاقتصادي. وفي النصف الثاني من القرن الماضي، قامت مصر بالعديد من المحاو لات لتنمية

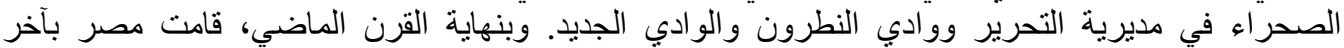

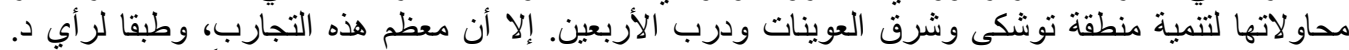

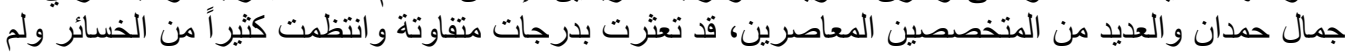

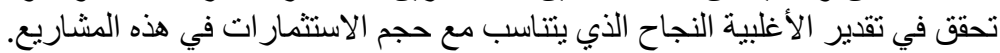

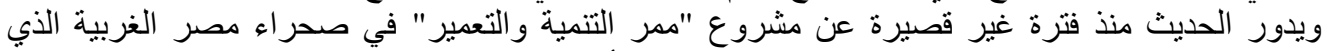

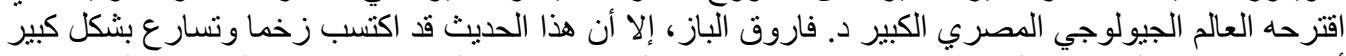

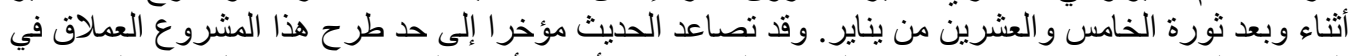

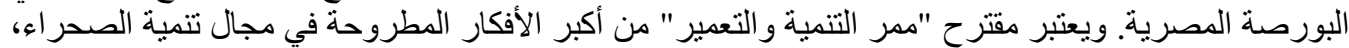

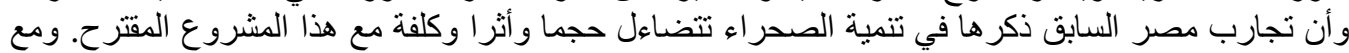

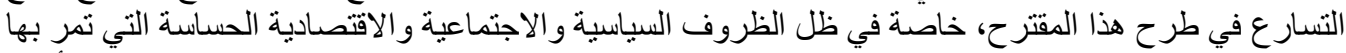

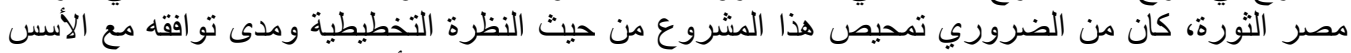

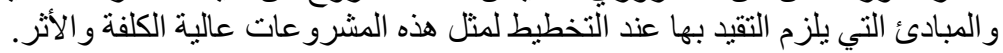

\section{أولاً: التعريف بالمشروع: أهدافه ومكوناته وتكلفته}

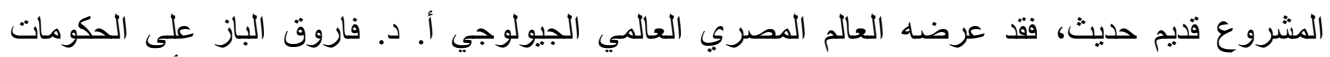

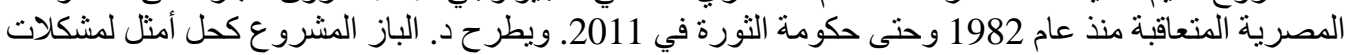

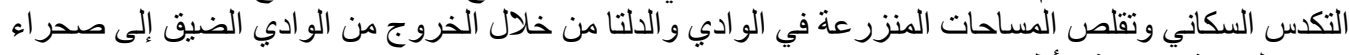

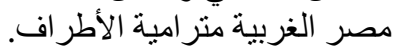

1-1 أهداف المشروع:

في ندوته بنقابة الصحفيين عام 2006 وكذللك طبقا لما ورد بكتابه عن المشروع وفي لقاء اته الصحفية، حدد الصدا

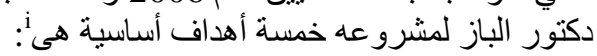

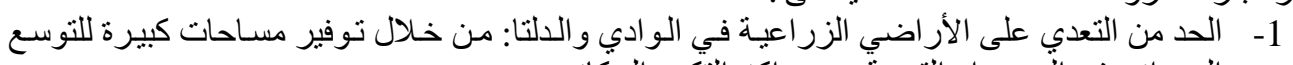

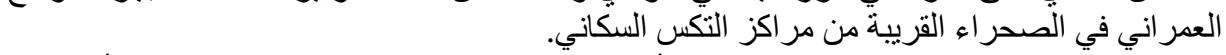

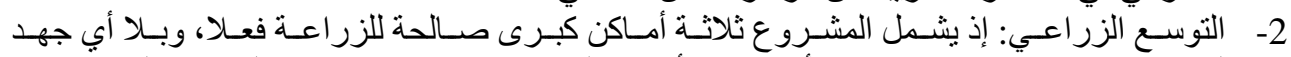

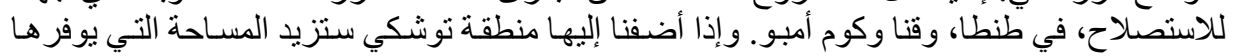

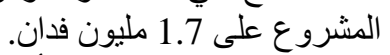
3- التتمية السياحية: وذلك في الأقصروفي منطقة الفيوم حول بحيرة قارون،التي يمكن استثمار ها سياحيا بشكل غير مسبوق.

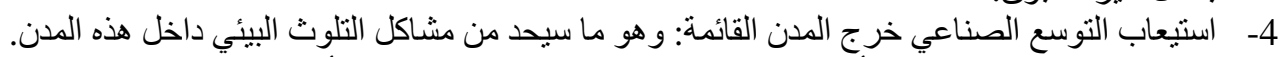

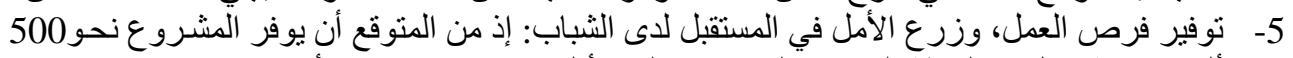

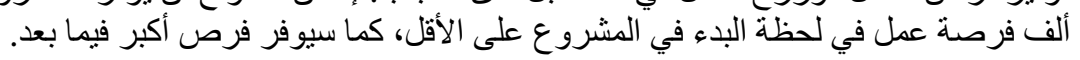

ويمكن إيجاز أهم أهداف المشروع في هدفين أساسيين، يمكن من خلالهما تحقيق الأهداف السابق ذكرها، وهما:

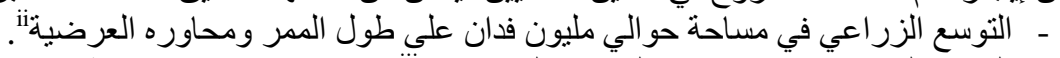

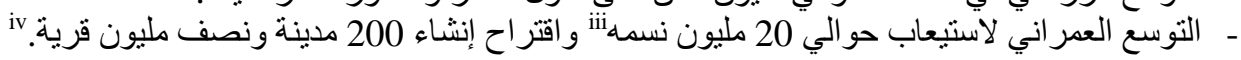

2-1

أما عن مكونات المشروع، فطبقا لما جاء بكتاب د. الباز عن المشروع وفي العديد من تصريحاته الصحفية

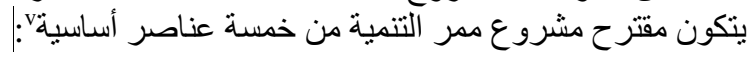




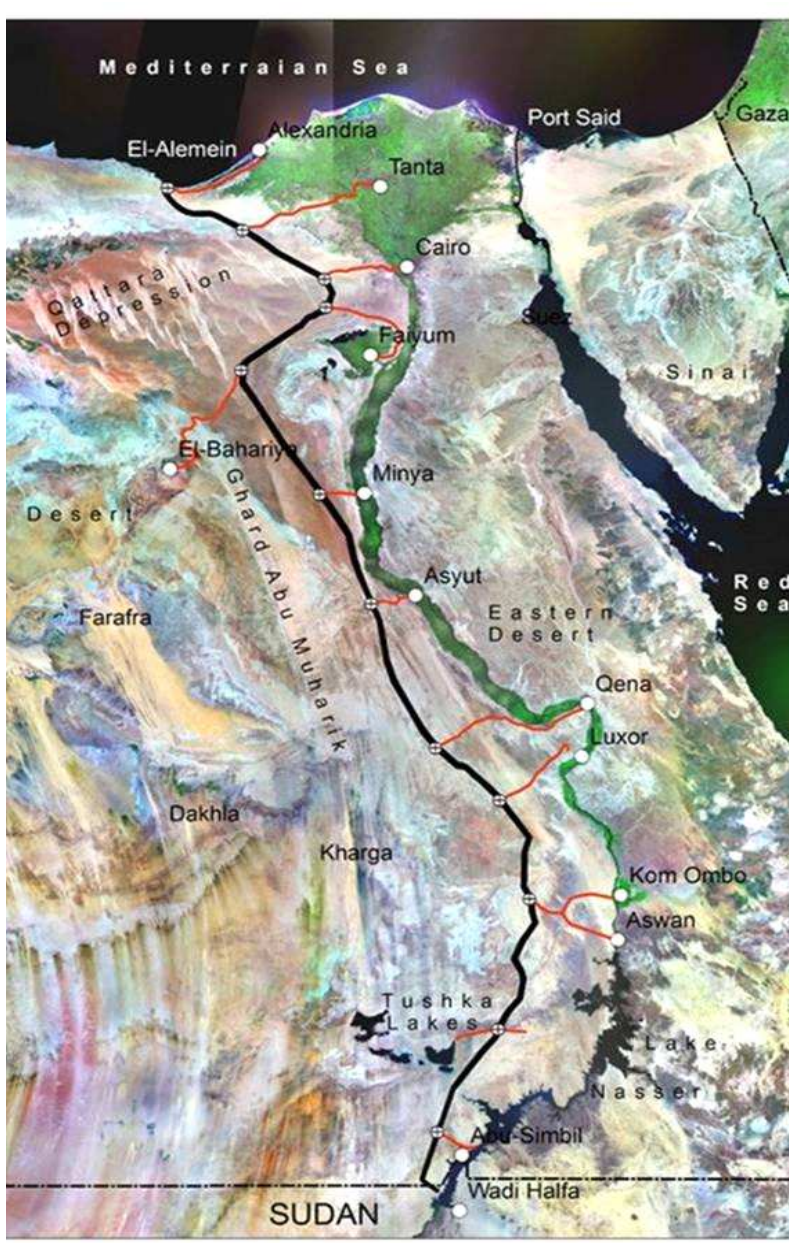

شكل رقم 1: مسار الممر الطولي بالمشروع.
ممر طولي: بطول حوالي 1200 كم من

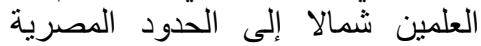
السودانية جنوبا عند أرقين/وادي العيد حلفا،

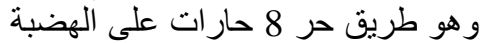
بعيدا عن الكثبان الرملية موازيا لمسار مجرى النيل على بعد 30-80 كم غربا الريا (شكل رقم 1). خط مياه عذبة: يتضمن المقترح أنبوب مياه من بحيرة ناصر أو قناة توشئي

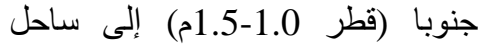

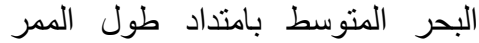
بغرض توفير مياه الثرب بامثرات ومواجهة احتياجات المنتجعات العمرانية على على لئل

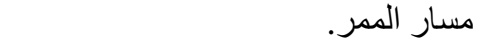

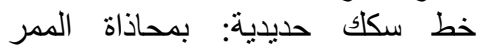
الطولي لنقل البضائع و الركاب. خط كهرباء بمحاذاة الممر الطولئ الركابي. محاور عرضية: 12 محور بأذبأطوال

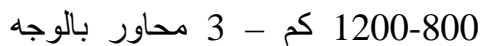
البحري (الإسكندرية، طنطا، القاهرة)،

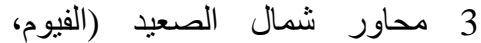

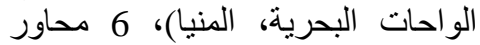

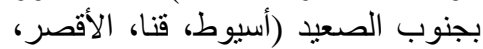
كوم أمبو، أسوان، توشئى، أبو سنبل).

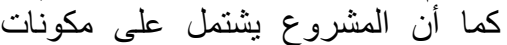

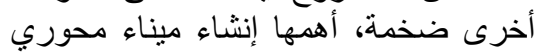
جديد في العلمين بدلا من ميناء الإسكندرية الذي أصبح، في رأي سيادته، متهالكا. وقِد أشتار د. الباز في في أحد لقاءاته الصحفية

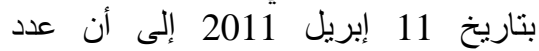
المحاور العرضية في المشروع قدئ ارتئ إنفع إلى إنى

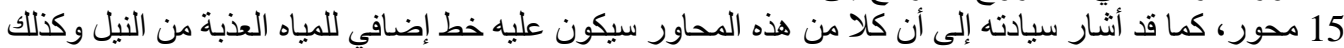

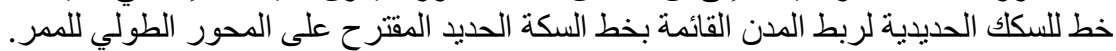

3-1 التكلفة التقديرية وأسلوب التمويل:

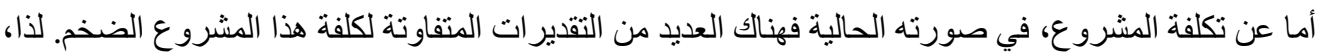

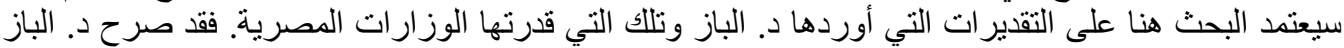

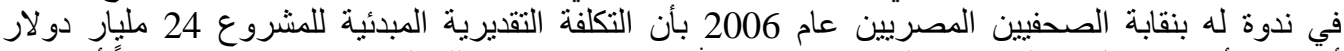

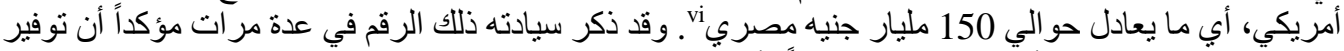

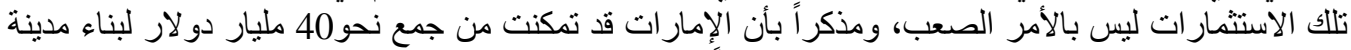

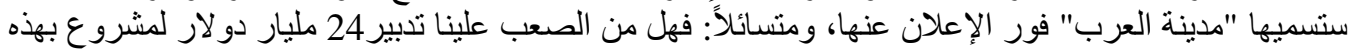

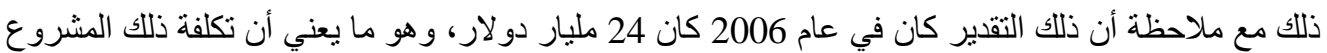

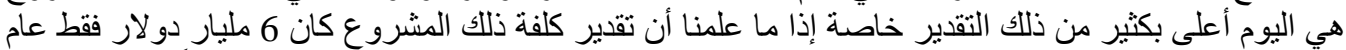

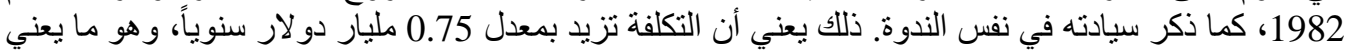


أن تكلفة المشروع الآن تصل إلى حوالي 28 مليار دو لار ـ وفي عام 2008، وقد قدرت اللجنة التي شكلتها وزارة

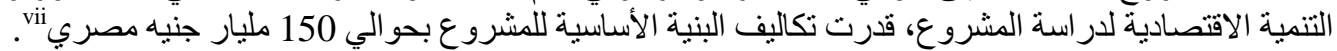

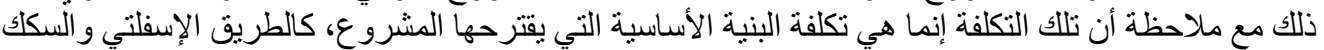

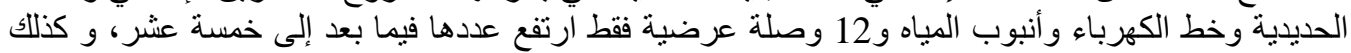

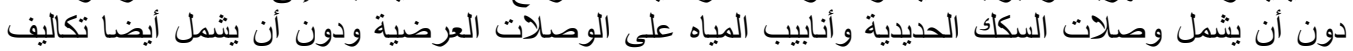

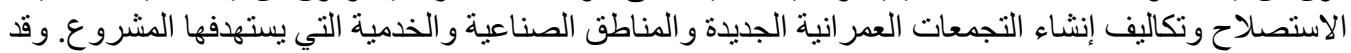

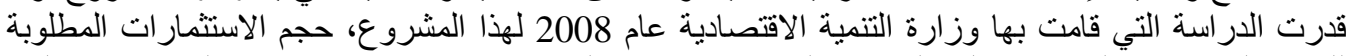
للتنمية الصناعية والزر اعية على المحاور العرضية في هذا المشروع حتى عام 2050 بحوالي التي 243.8 مليار

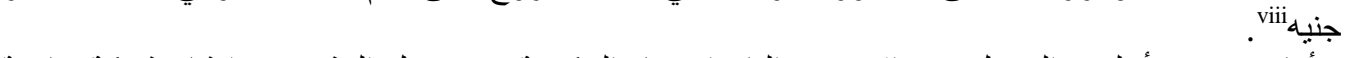
أما من حيث أسلوب التمويل، فقد اقترح د. الباز استبعاد الحكومة من تمويل المشروع و إنشاء شركة خاصة

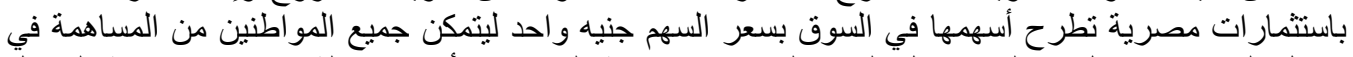

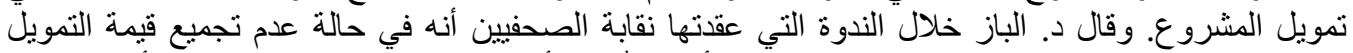

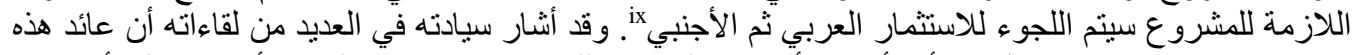

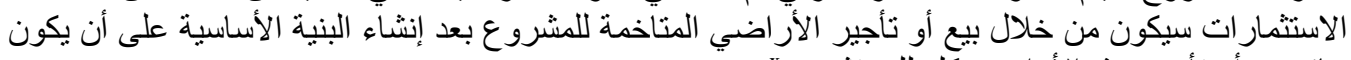

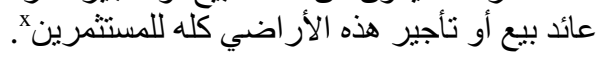

\section{ثانياً: نقاط الاتفاق مع المشروع}

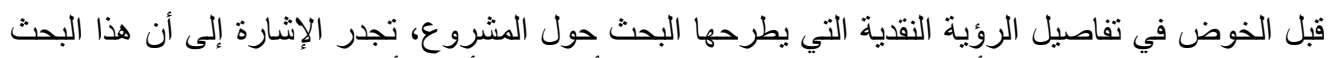

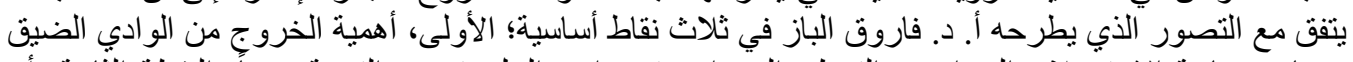

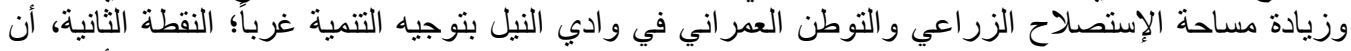

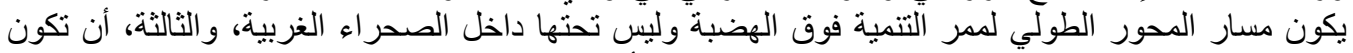

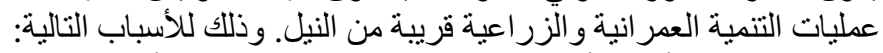

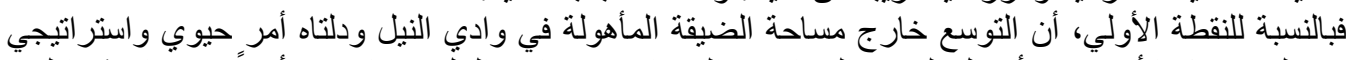

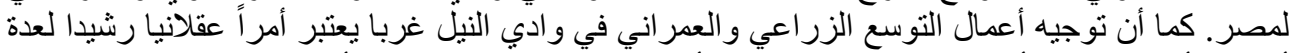

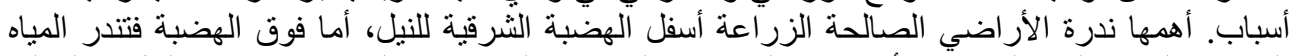

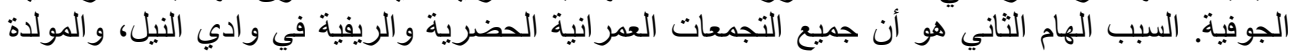

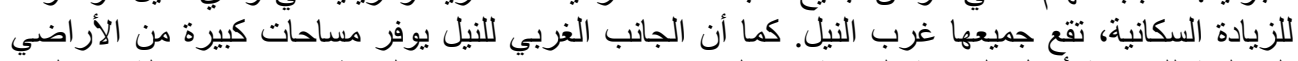

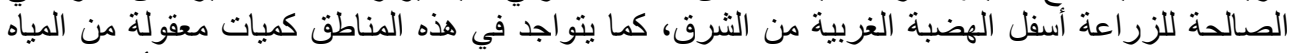

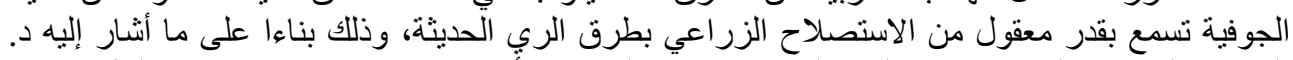

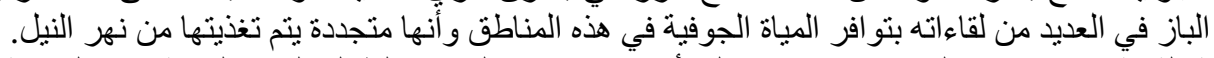

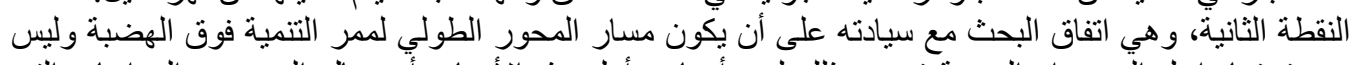

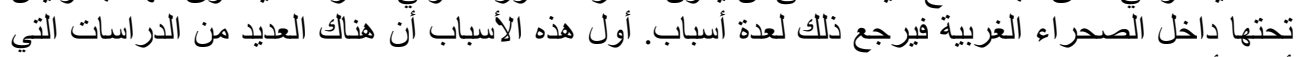

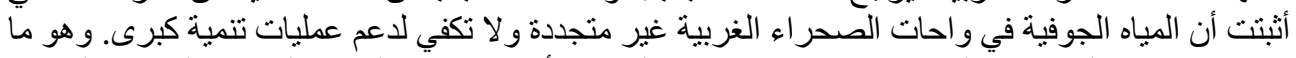

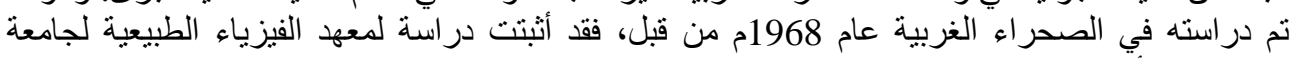
هايدلبرج، ألمانيا Heidelberg

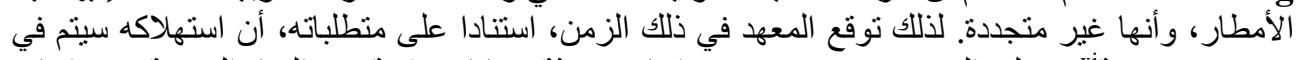

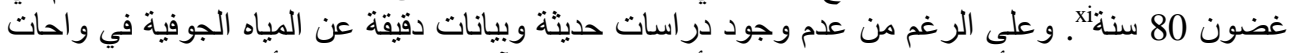

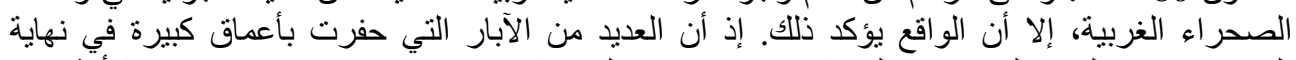

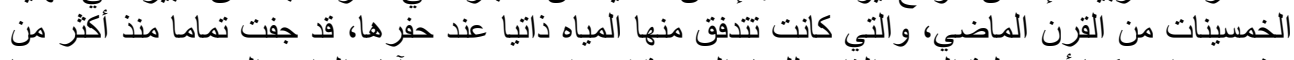

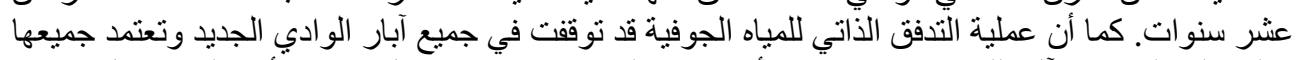

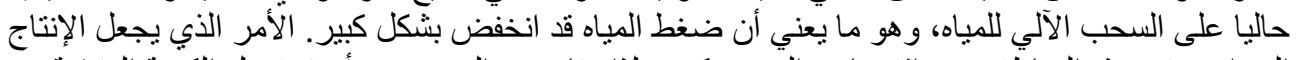

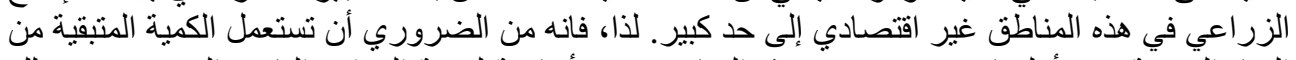

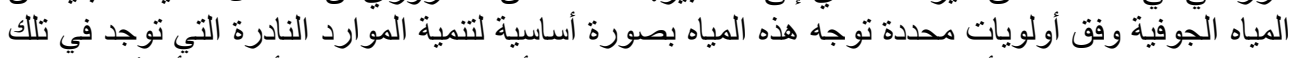

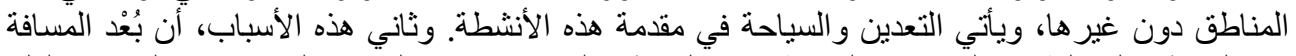

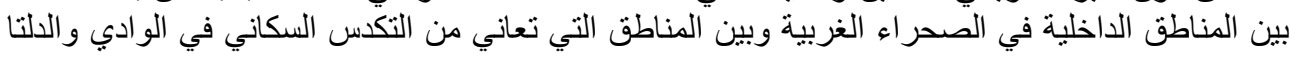


يحد بشكل كبير من إمكانية نقل كمية كبيرة من الزيادة السكانية في الوادي ولدلتا إلى هذه المناطق. فعلى التى

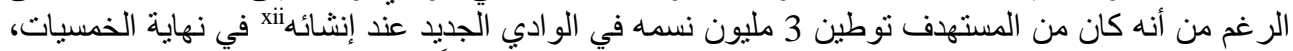

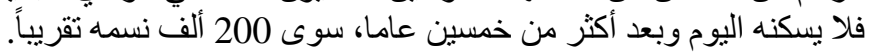

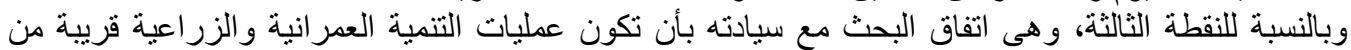

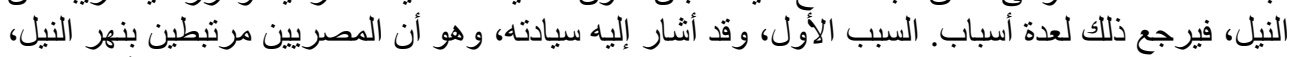

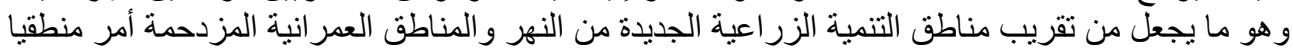

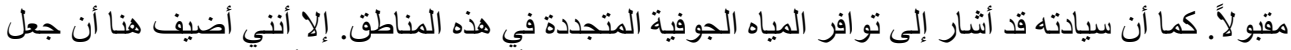

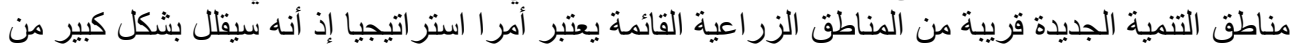

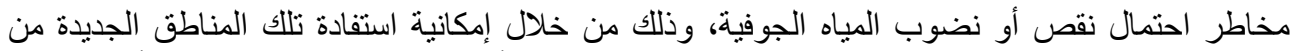

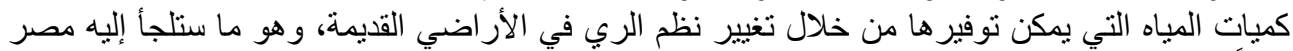

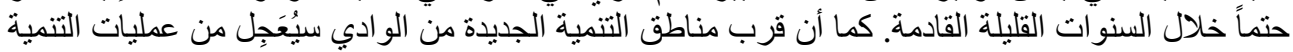

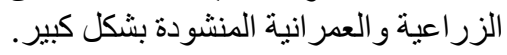

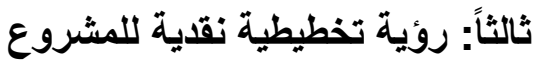

و على الرغم من نقاط الاتفاق السابق ذكرها، فإن للبحث بعض الانتقادات المتعلقة بالجوانب التخطيطية للمشروع، و التي يمكن إجمالها في النقاط التالية:

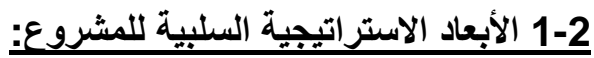

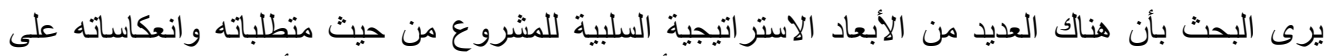

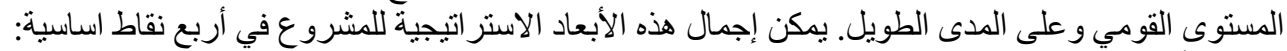

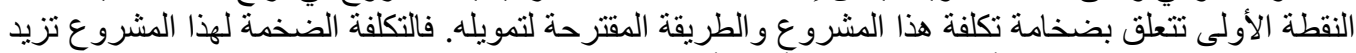

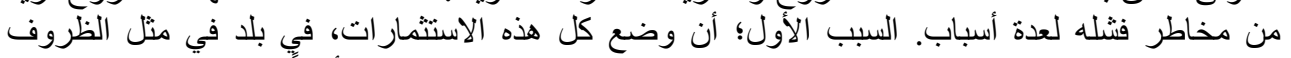

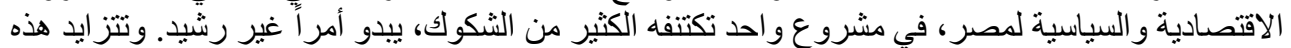

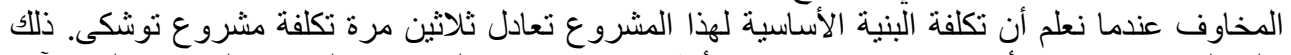

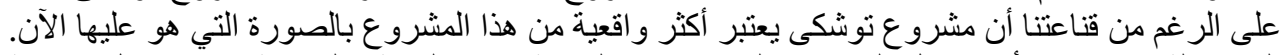

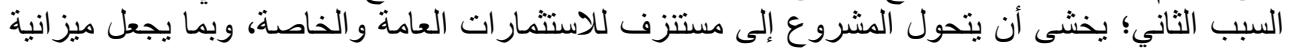

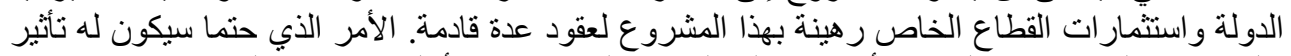

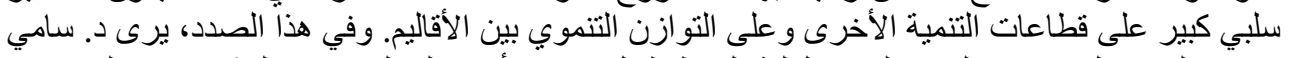

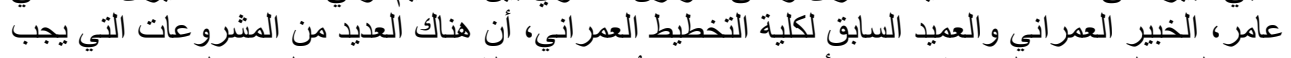

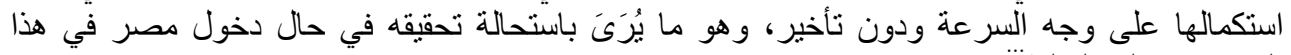

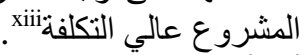

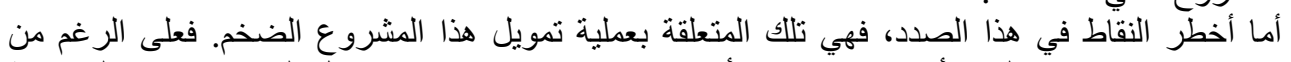

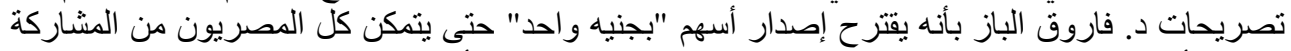

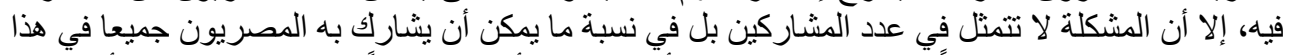

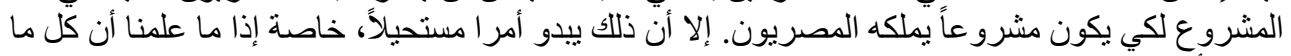

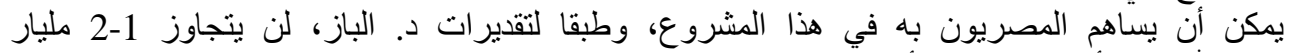

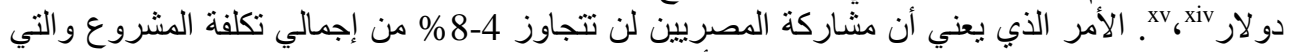

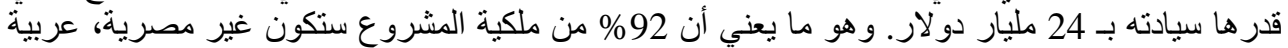

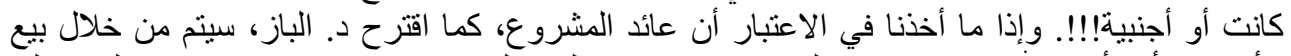

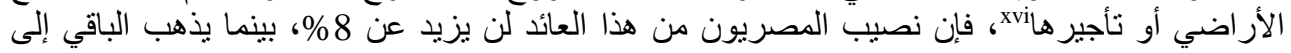

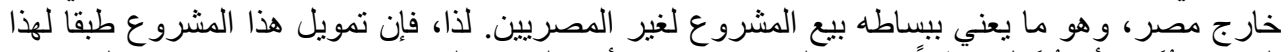

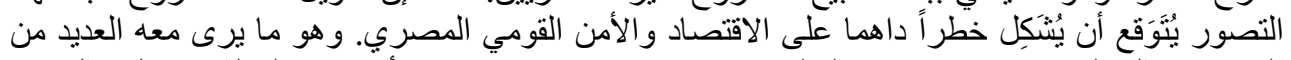

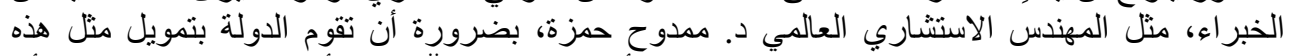

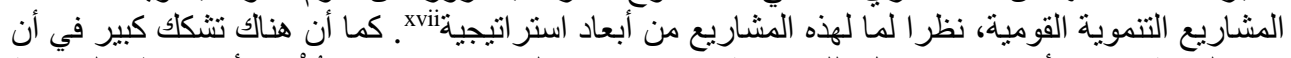

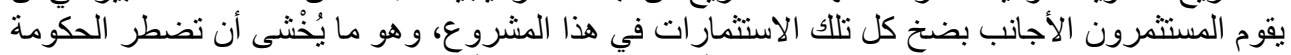

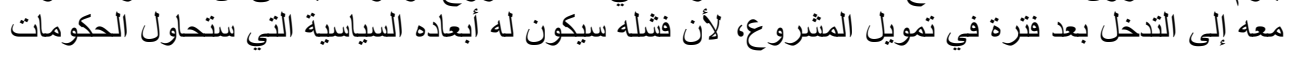


تفاديها. وهو ما يؤكده د. مصطفى السعيد، وزير الاقتصاد الأسبق، والذي يرى بأن التمويل الأجنبي إذا ما

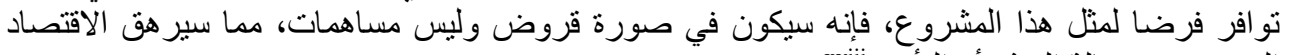

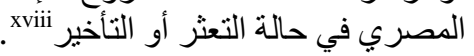

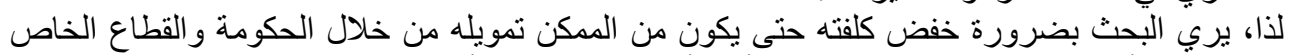

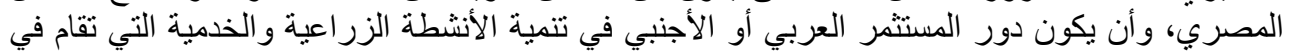

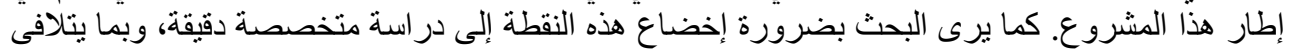
المخاوف السابق الإشارة إليها.

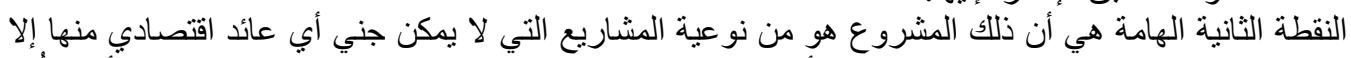

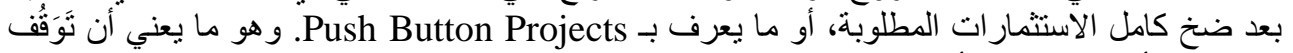

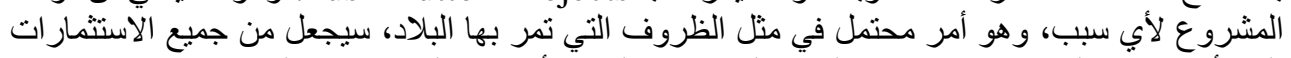

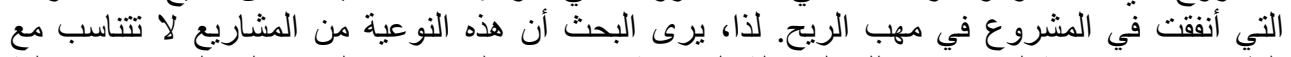

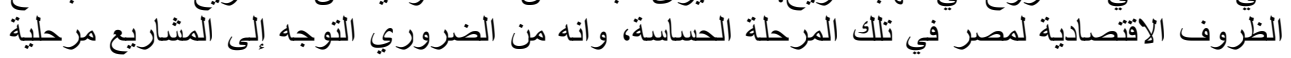

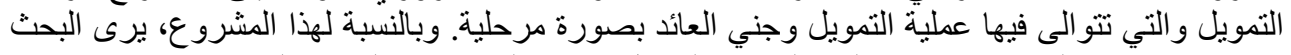

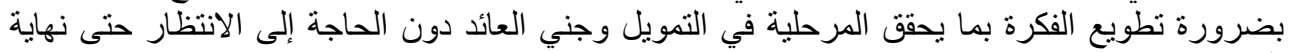

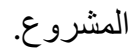

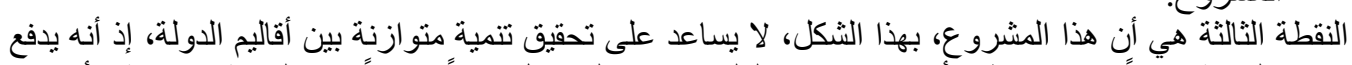

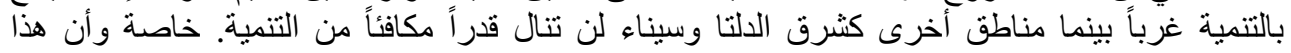

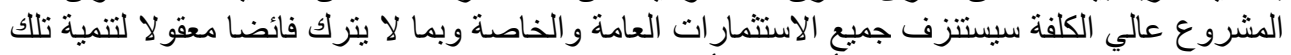

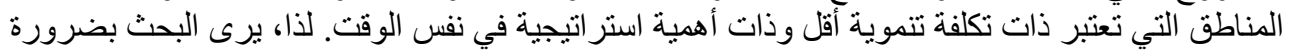

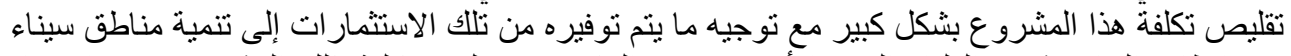

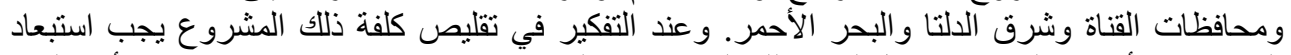

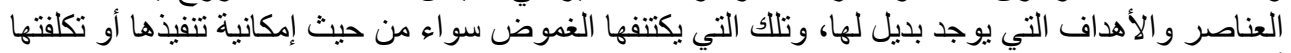

أو جدو اها.

النقطة الرابعة هى أن ذلك المشروع، بطريقة التمويل المقترحة من خلال السماح للمستثرين بييع الأرض لتمويل

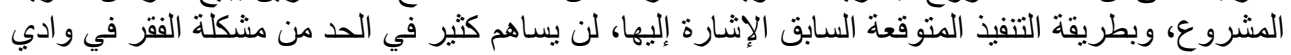

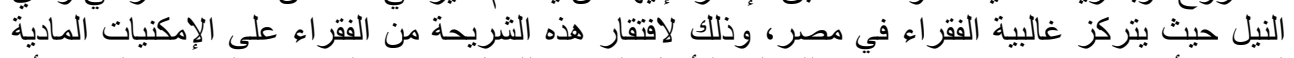

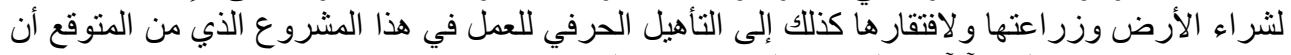

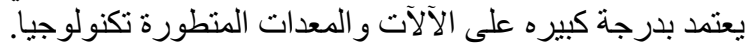

\section{2-2 غياب الواقعية والموازنة بين التكلقة والعائد}

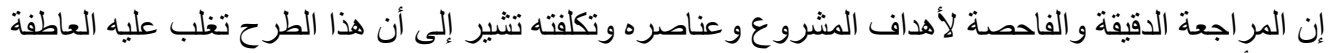

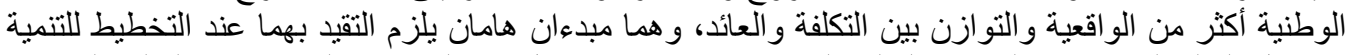

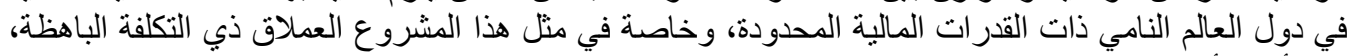

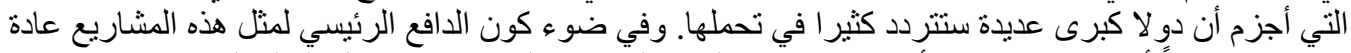

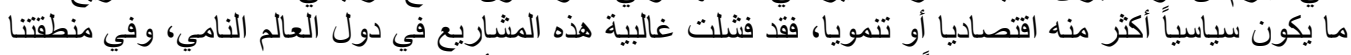

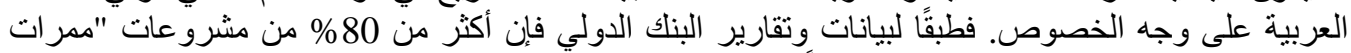

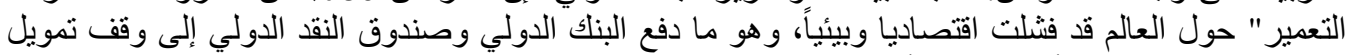

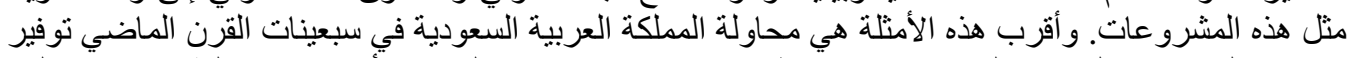

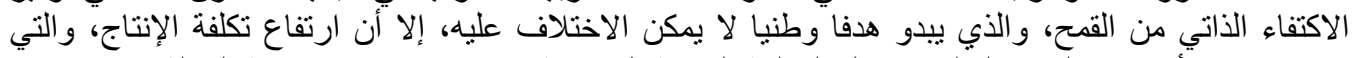

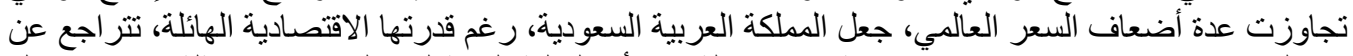

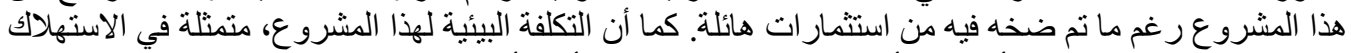

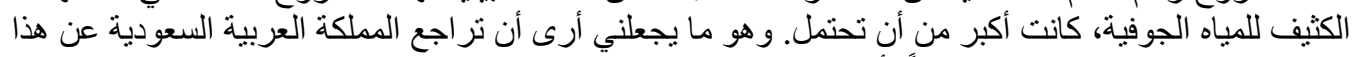

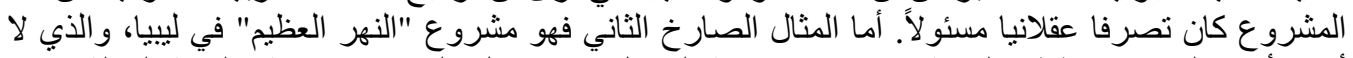

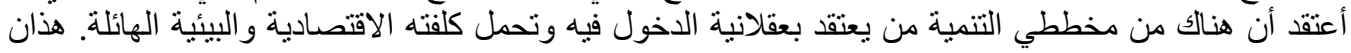

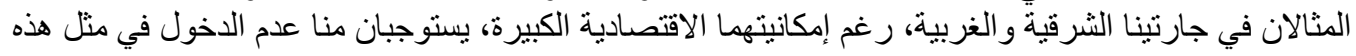


المشاريع، أو على الأقل الدراسة الدقيقة والمتأنية لأهدافها ومكوناتها وتكلفتها، خاصة وأن أن تمويل مثل هذه أنها

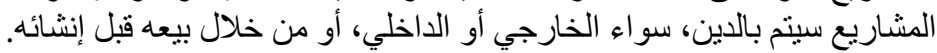

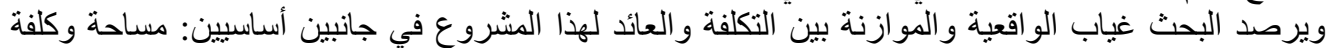
التوسع الزر اعي وكذللك ما يطرحه المشروع الئرونة من توسع عمر اني مستهدف.

\section{1-2-2 مساحة وكلفة التوسع الزراعى الأي يتيحه المشروع:}

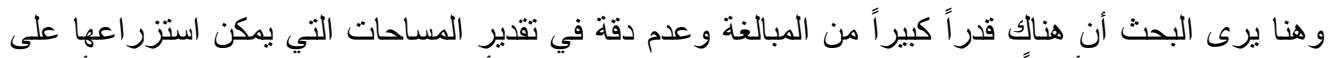

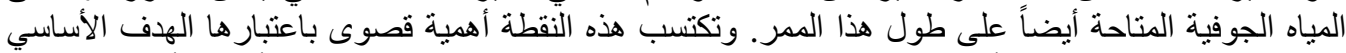

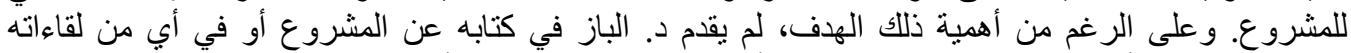

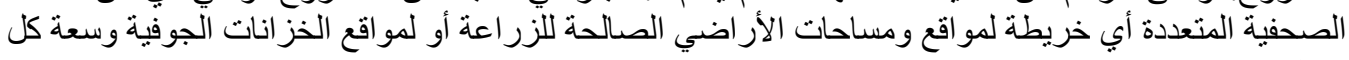

من ناحية ثانية، بينما يقدر د. الباز المساحات التي يمكن استزر اعها اعتمادا على المياه الجوفية بحو الي مليون

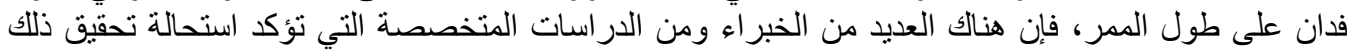

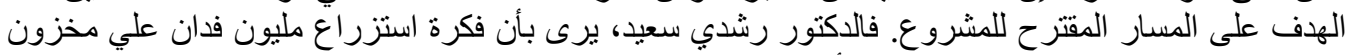

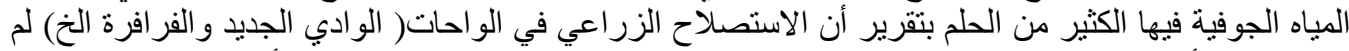

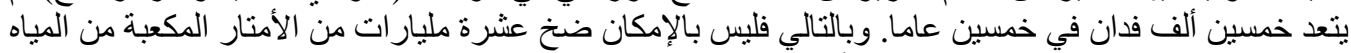

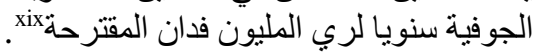

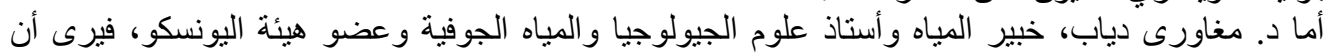

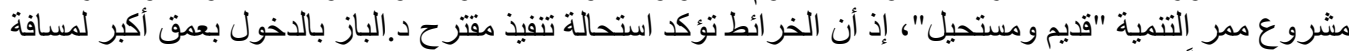

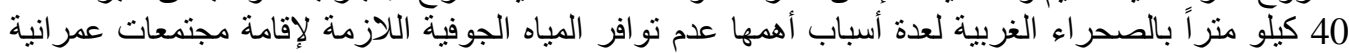

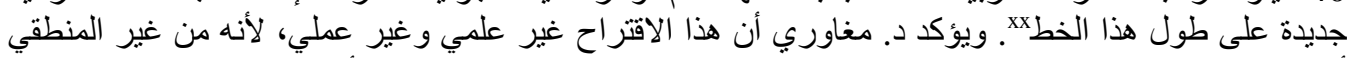

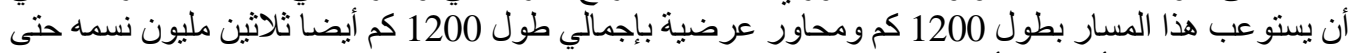

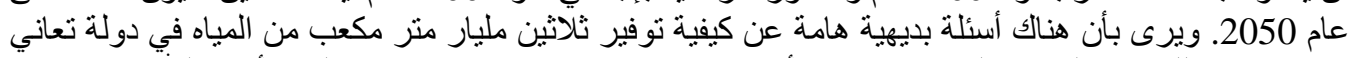

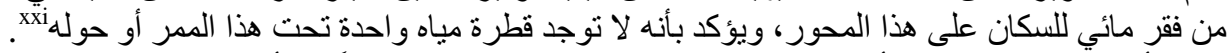

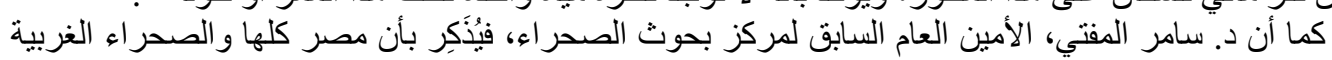

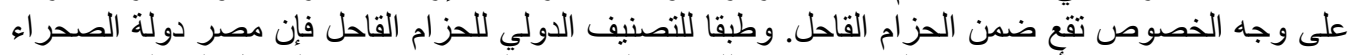

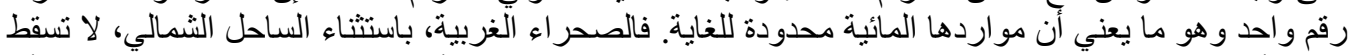

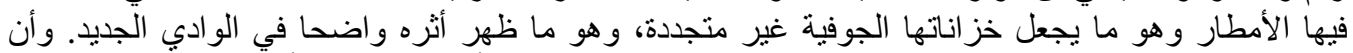

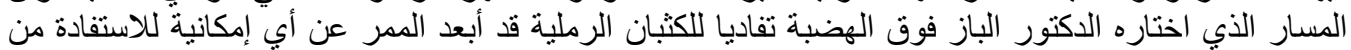

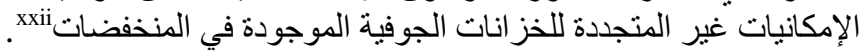

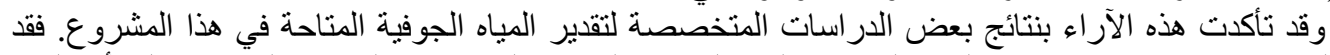

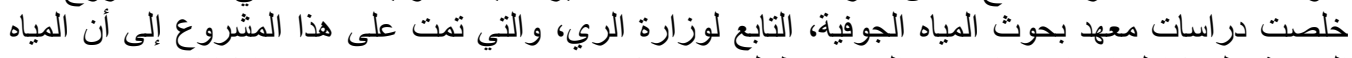

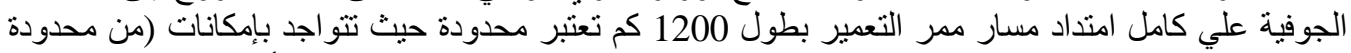

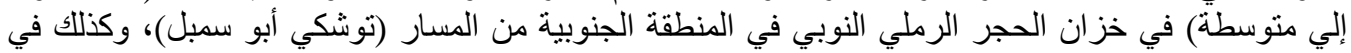

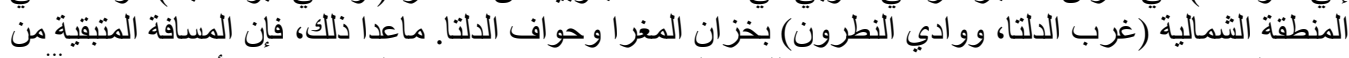

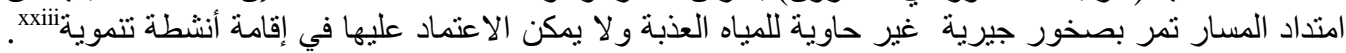

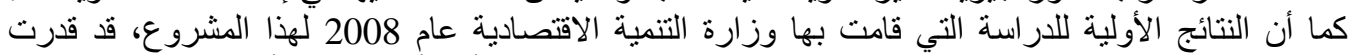

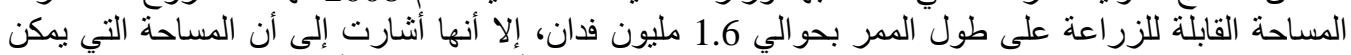

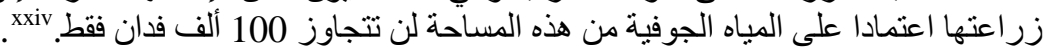

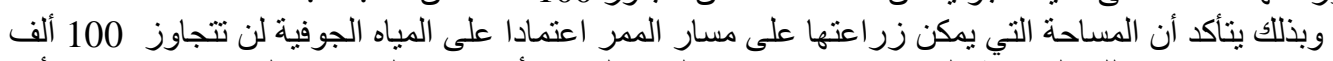

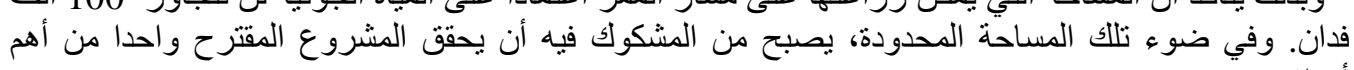

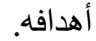

من ناحية ثانية، ونظر المحدودية المساحة التي يمكن زر اعتها في إطار هذا المشروع وفي ضوء الإهي التكلفة العالية

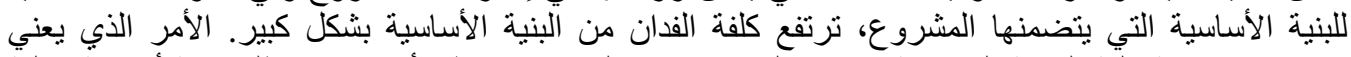

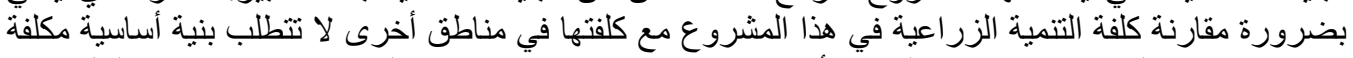

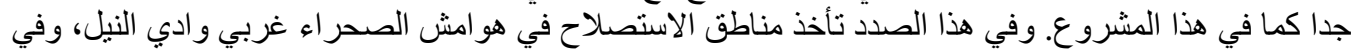


شرق وغرب الدلتا ومنطقة القناة، وفي المناطق الموازية لساحل شمال سيناء وساحل مطروح أولوية متقدمة

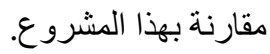

\section{2-2-2 حجم وطبيعة الاستيعاب العمر انى للمشروع:}

وهنا يرى البحث أيضا أن هناك مبالغة كبيرة في تقدير حجم التوسع العمراني الذي يمكن أن يتيحه هذا

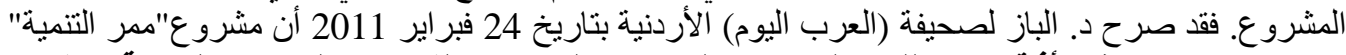

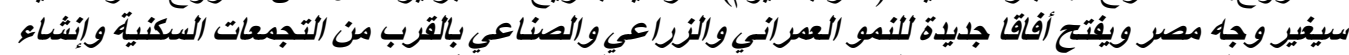

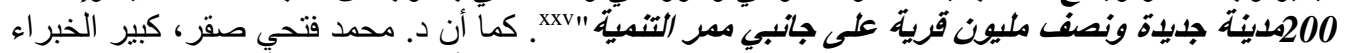

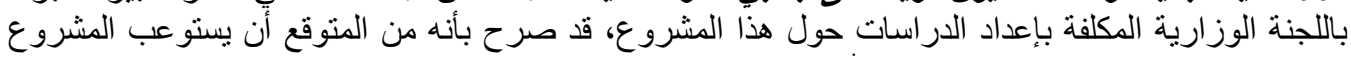

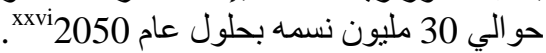

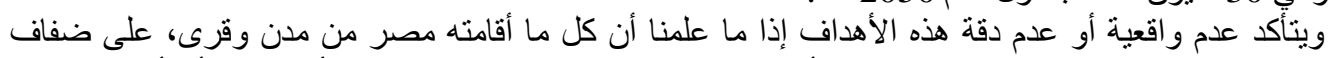

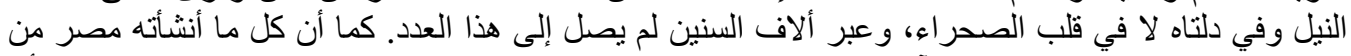

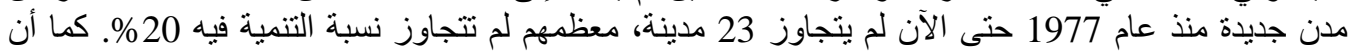

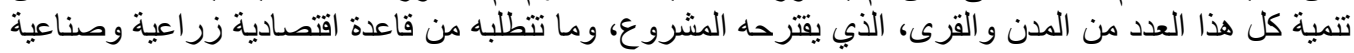

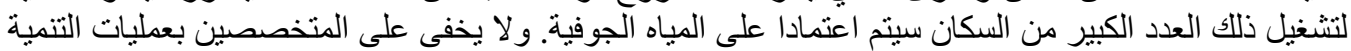

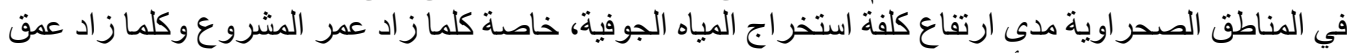

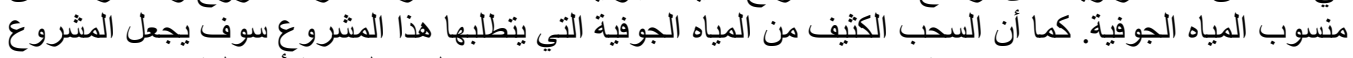

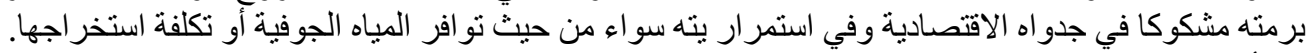

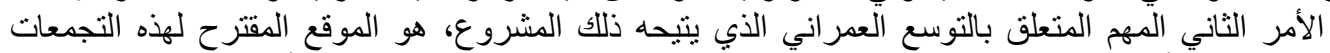

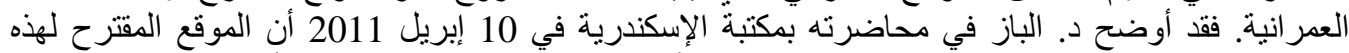

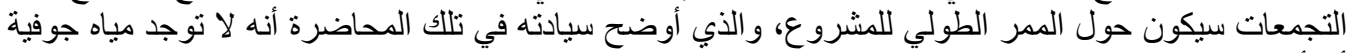

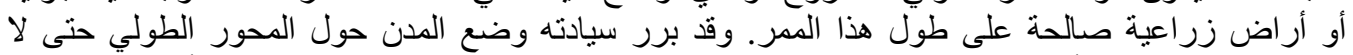

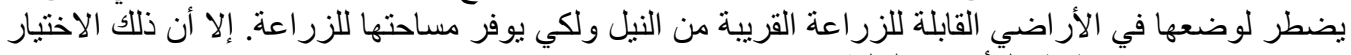

يعتبر غير مناسب تخطيطيا لتلأسباب التالية:

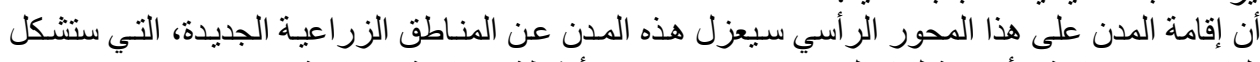

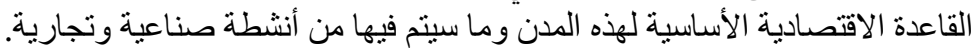

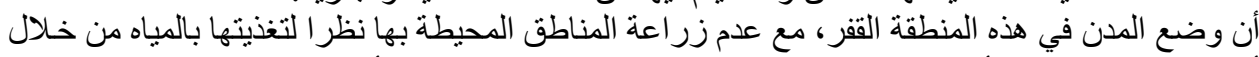

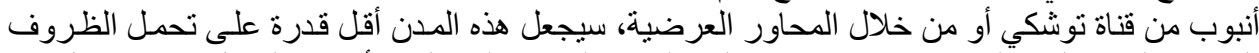

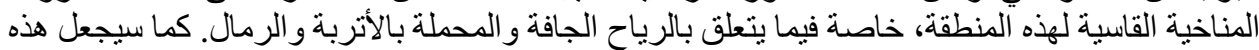

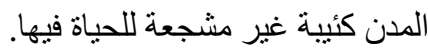

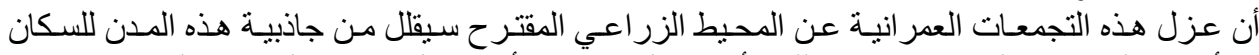

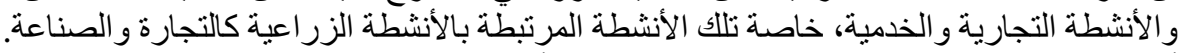

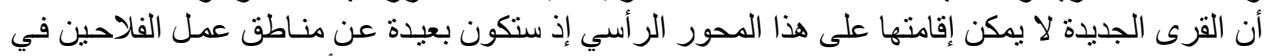

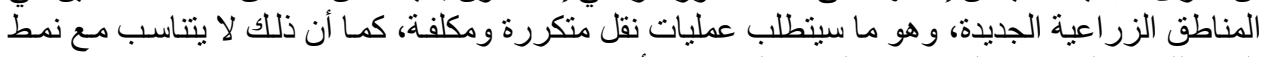

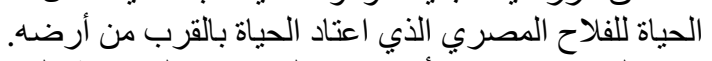

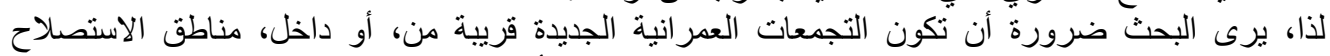

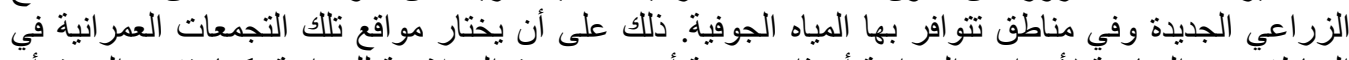

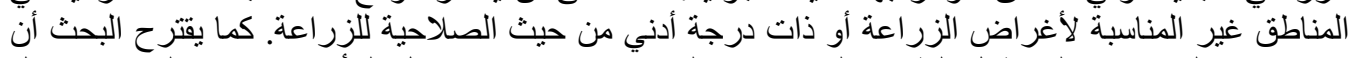

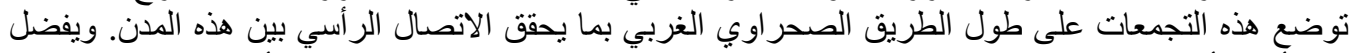

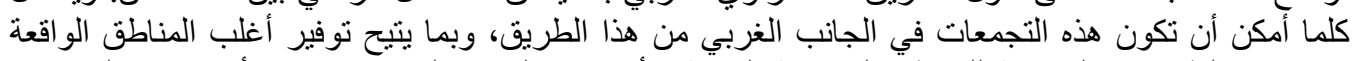

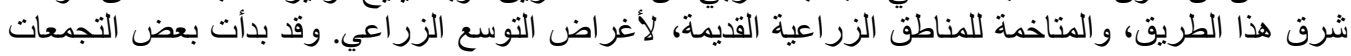

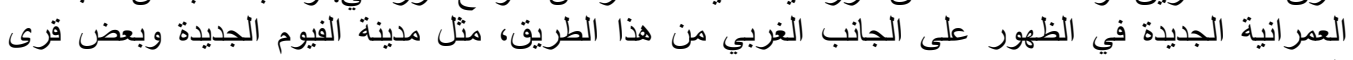

\section{3-2-2 المحور الرأسى (الطريق الأسفلتى والسكة الحديد) ..... هل هو ضرورة؟}

تُشَكِل تكلفة الطريق الإسفلتي والسكك الحديدية على المحور الطولي للمشروع النصيب الأكبر من إجمالي كلفة

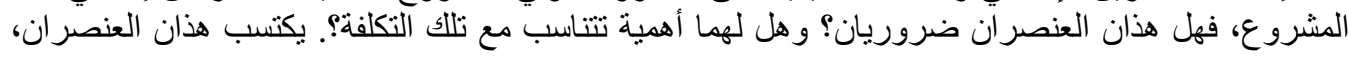




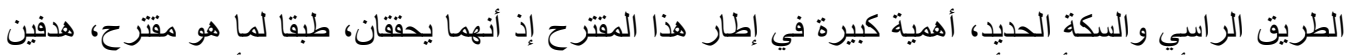

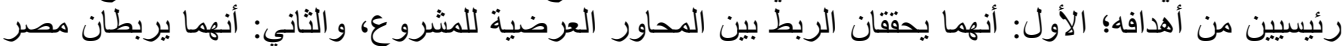

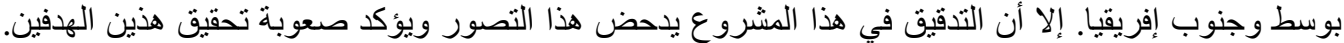

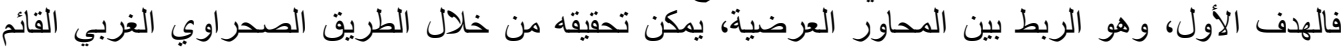

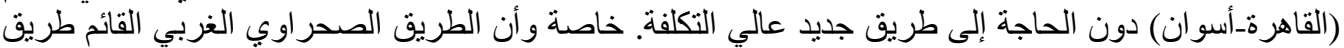

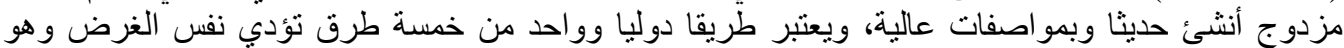

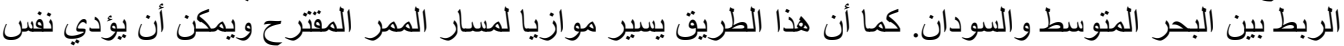

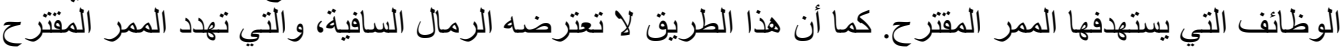

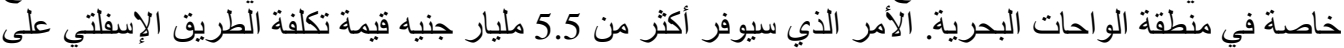

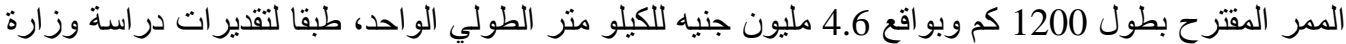
التنمية الاقتصادية عام 2008.

أما الهدف الثاني، و هو الربط مع وسط وجنوب إفريقيا، فمشكوك فيه لسبيين. الأول: أن هذا الربط من خلال

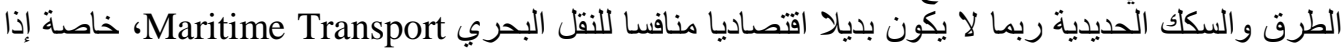

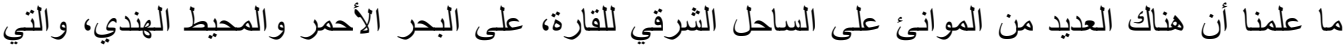

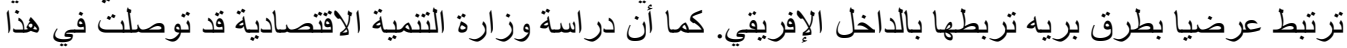

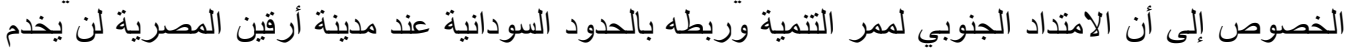

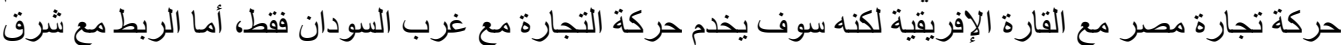

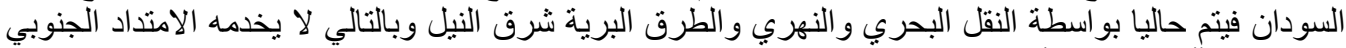

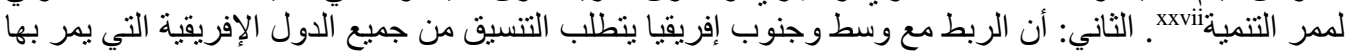

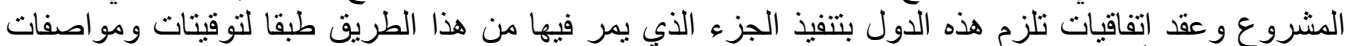

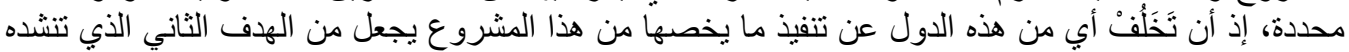

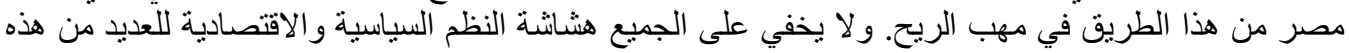
الدول. مهن. ويتأكد عدم واقعية هذا العنصر إذا ما علمنا بكلفته الباهظة. فطبقا لتقديرات در اسة وز ارة التتمية الاقتصادية عام

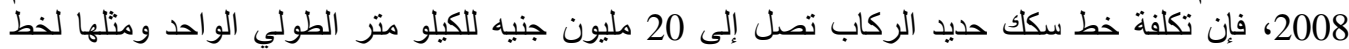
البضائع بطول الممر الر أسي وبطول أكثر من 1200 كم، بإجمالي تكلفة أكثر من

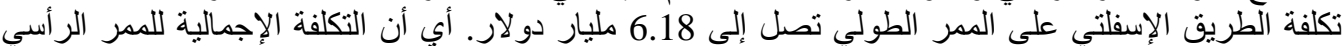

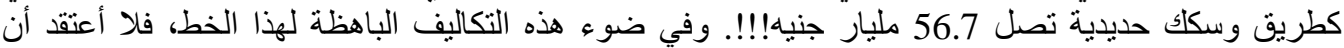

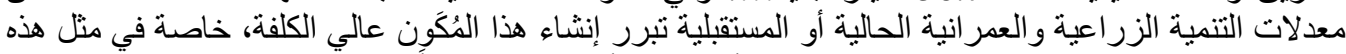

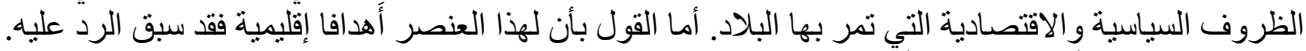

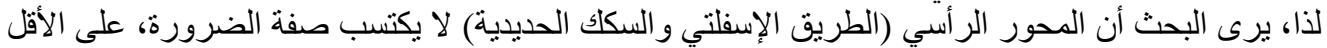

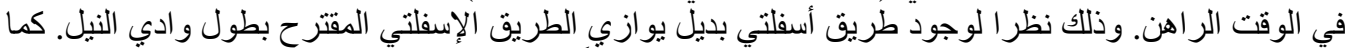

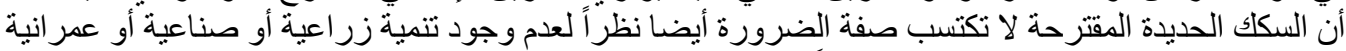

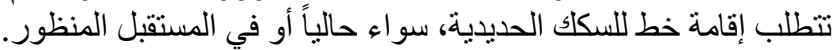

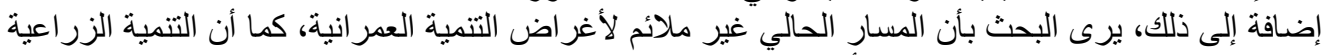

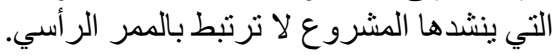

\section{ـ عدم ملاءمة المسار الحالي للممر الطولي لأغراض التنمية العمرانية:}

على الرغم من اتفاق البحث مع د. الباز في ضرورة أن يكون الممر فوق الهضبة وليس أسفلها في داخل

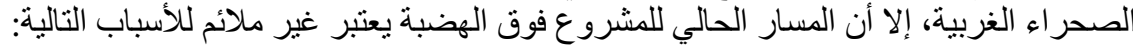

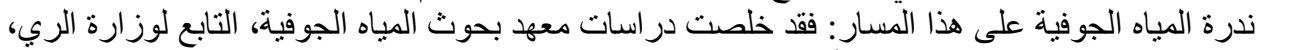

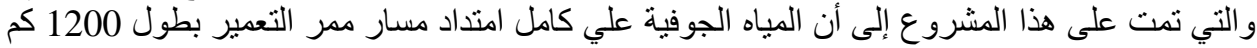

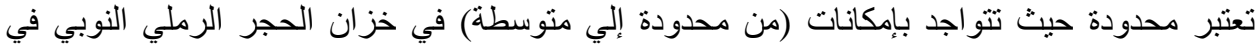

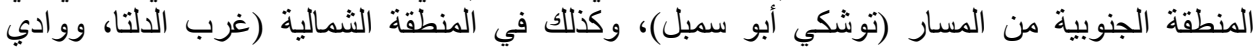

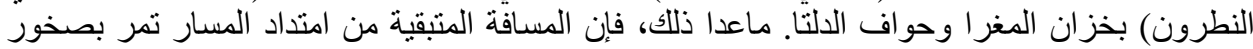

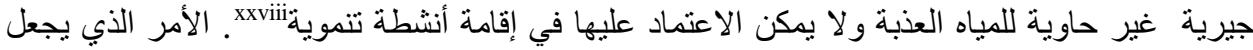


من الصعب للغاية تتمية أي من الموارد الطبيعية حول هذا المحور أو القيام بأي أعمال تشجير أو حماية

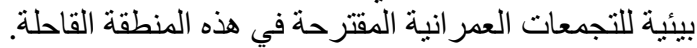

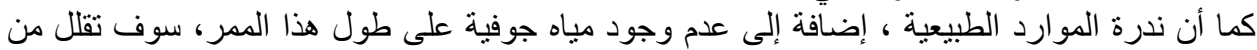

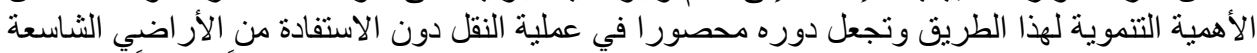

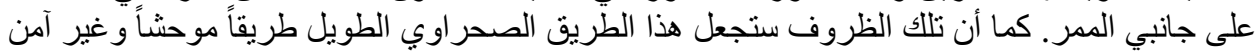
حتى لعمليات النقل.

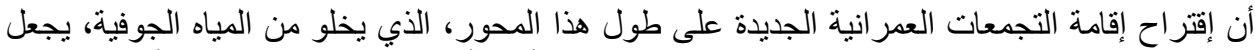

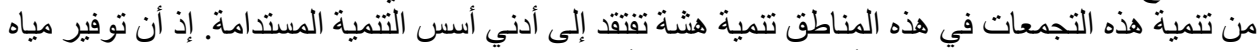

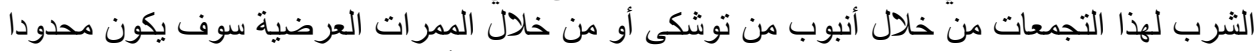

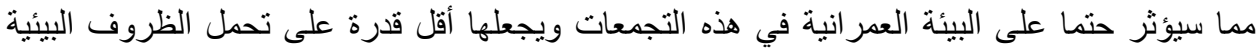
القاسية لتلك المناطق، كما بجعلها أقل جاذبية للسكان.

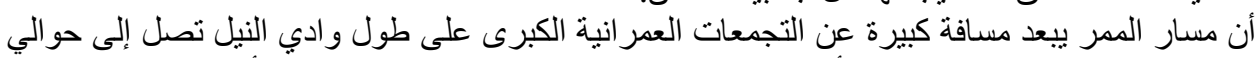

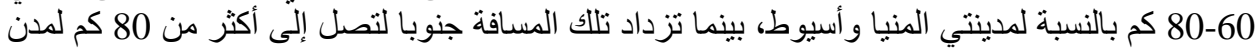

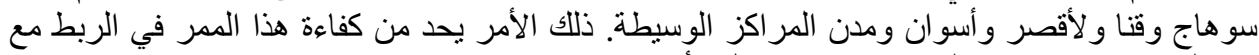

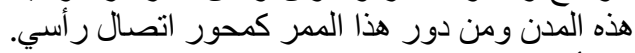

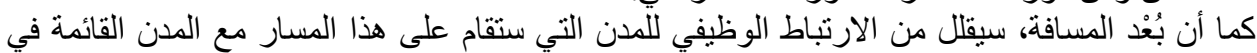

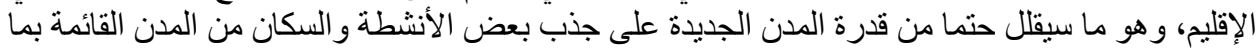

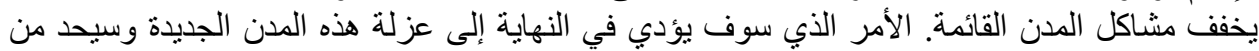

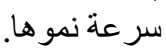
لذا، فإن المسار الحالي للمحور المألمأسي لممر التتمية المقترح يعتبر غير ملائم ويجب إعادة ترسيم مسار دذلك

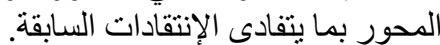

\section{ـ عدم ارتباط التنمية الزراعية والعمر انية بالمحور الرأسي (الطريث الطولي والسكك الحديدية):}

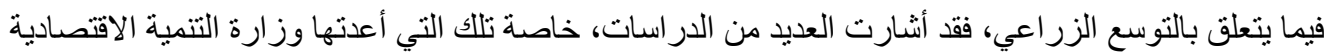

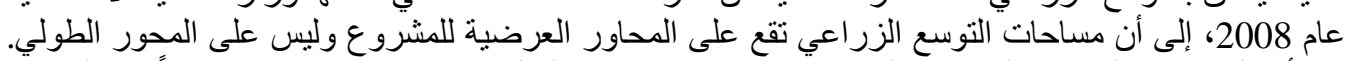

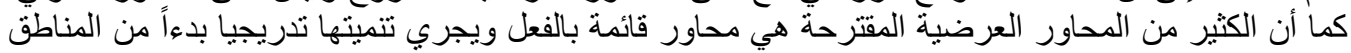

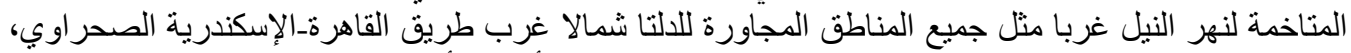

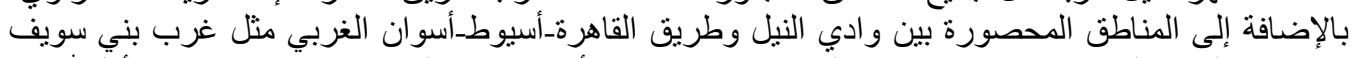

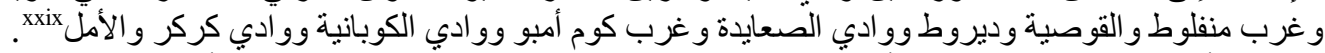

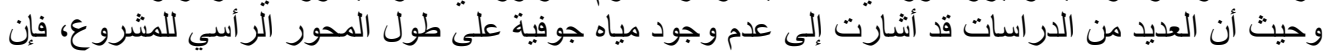

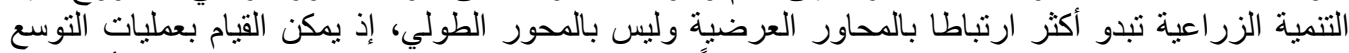

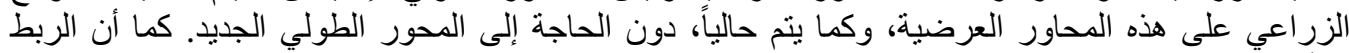

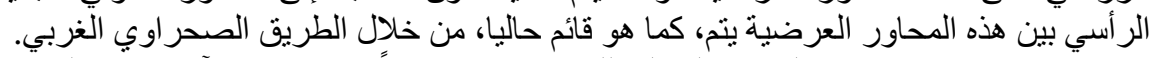

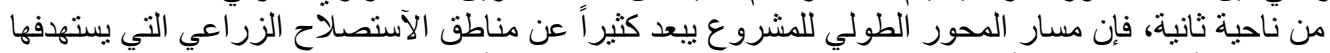

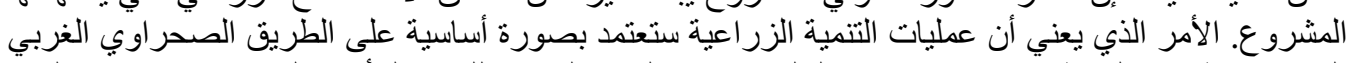

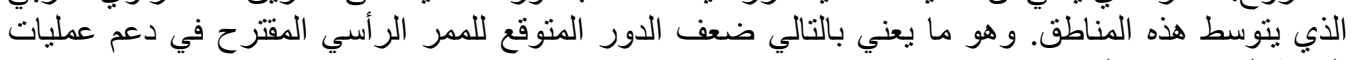

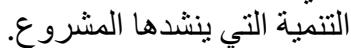
أما فيما يتعلق بالتتمية العمر انية، فقد اتضح من التئه النقاط السابقة أن ممر التتمية المقتر ح، بمساره الحالي، لا يناسب

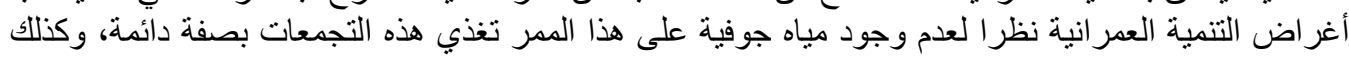

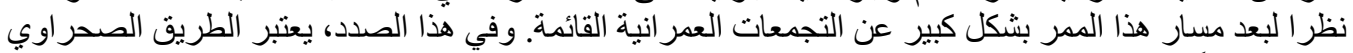

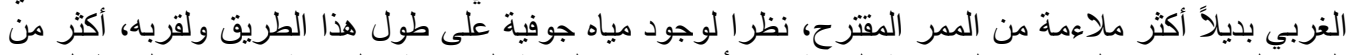

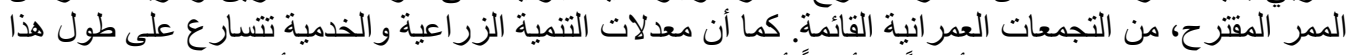

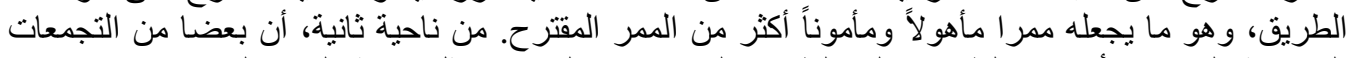

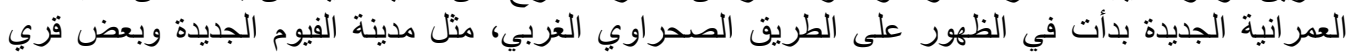

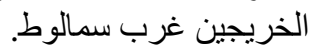

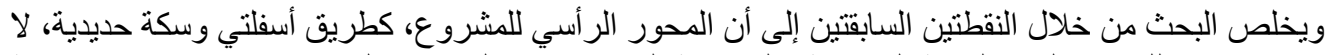

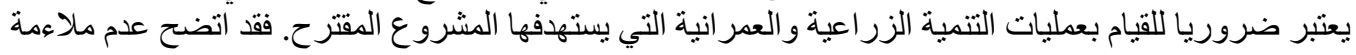


المسار الحالي للممر الطولي لأغراض التتمية العمرانية، كما أن عمليات التتمية الزراعية لا ترتبط بالمحور

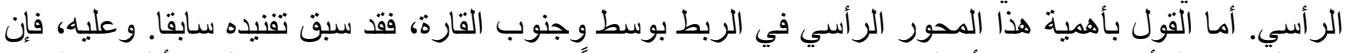

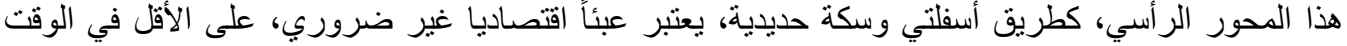

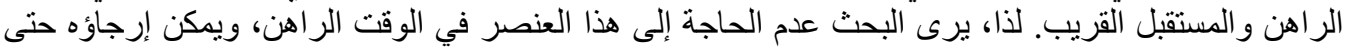

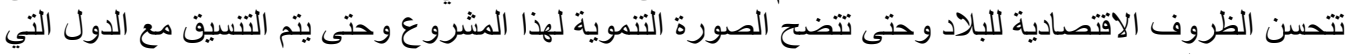

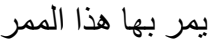

\section{4-2-2 أنبوب للمياه من توشكى حتى العلمين!!! .... هل هو ضرورة؟}

على الرغم من التكلفة العالية لذلك الأنبوب، و على الرغم من الصعوبات الفنية التي تعترض تنفيذ ذلك الأنبوب، فإنتي أرى عدم الحاجة إليه من الأساس لعدة أسباب.

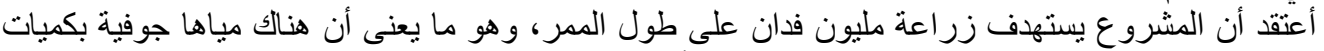

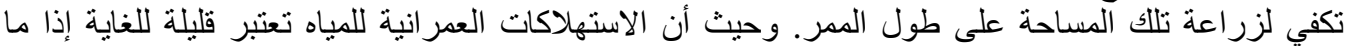

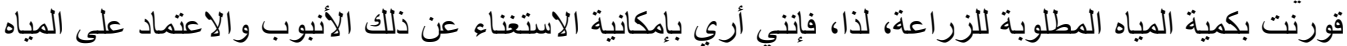

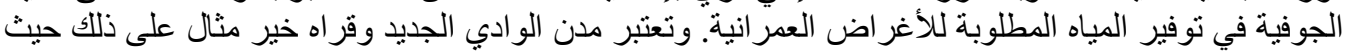

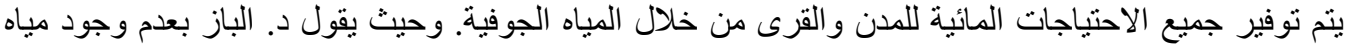

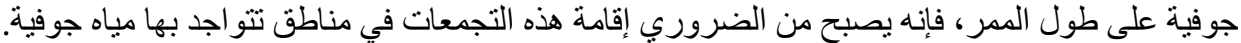

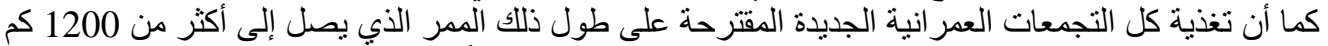

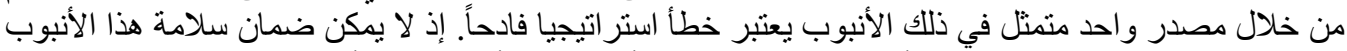

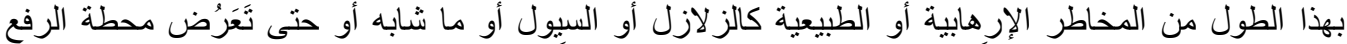

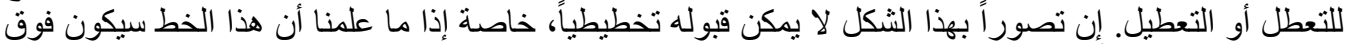

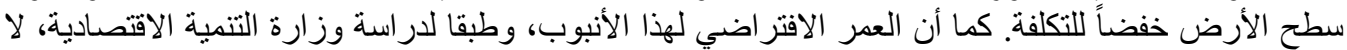

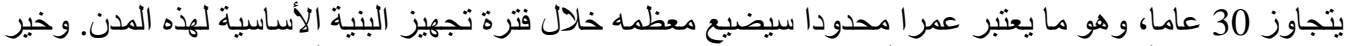

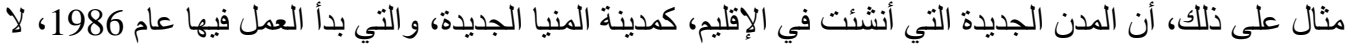

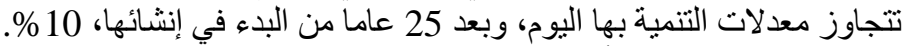

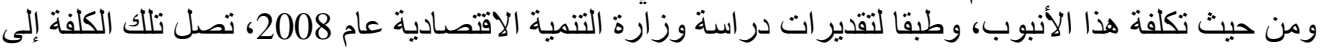

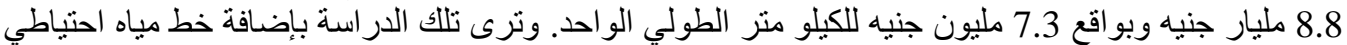

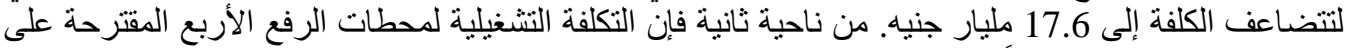

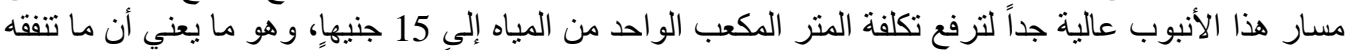

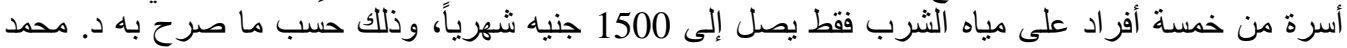

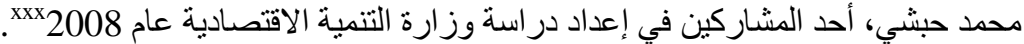

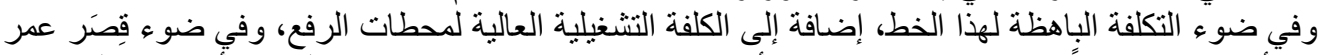

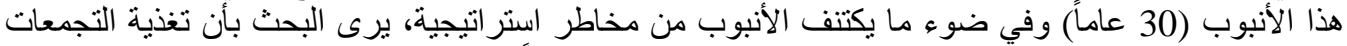

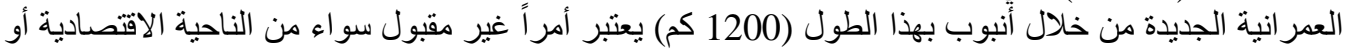
الاستر اتيجية. و هو ما يستوجب إنشاء هذه هذه المتجمعات في مناطق تتو افر بها مياه جوفية بما يضدن استدامة عملية

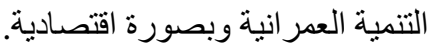

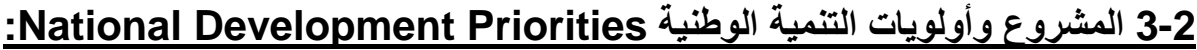

علم الأولويات، أو فقه الأولويات، مبدأ فقهي ثابت كما أنه مبدأ تخطيطي أصيل وضروري. فمن يتجاوز

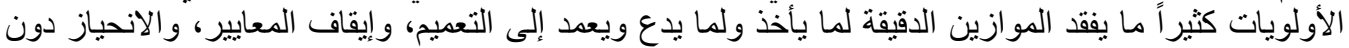

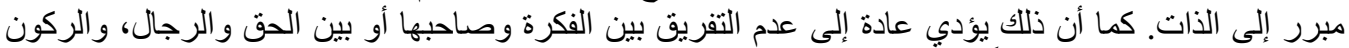

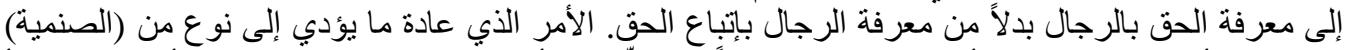

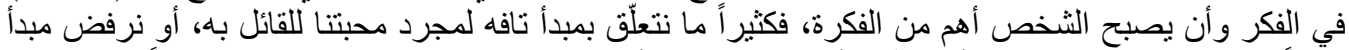

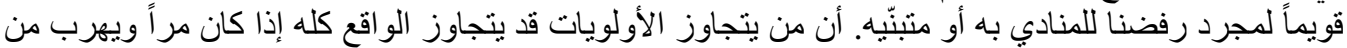

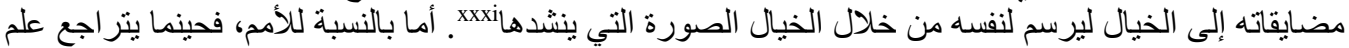

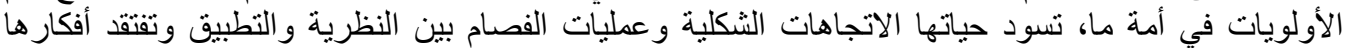
وممارساتها كثير ا من الأسس التخطيطية الرشيدة كالو اقعية و إمكانية التطبيق وكذلك الموازنة بين بين التكلفة و العائد. 
وفي ضوء هذا الفهم لعلم الأولويات، فليس كل ما هو جيد يجب عمله، بل أن كونه جيدا مرتبط في الحقيقة

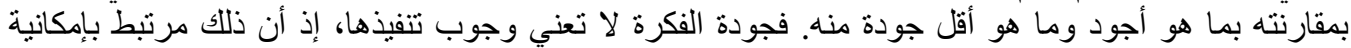

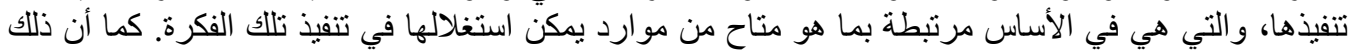

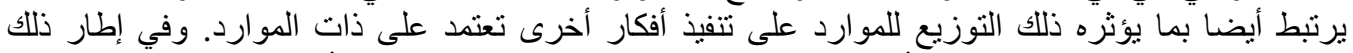

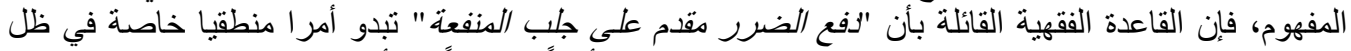

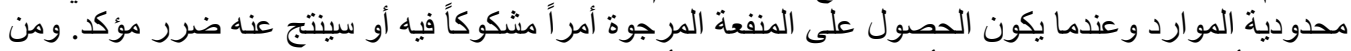

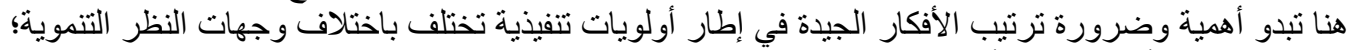

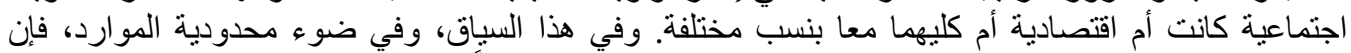

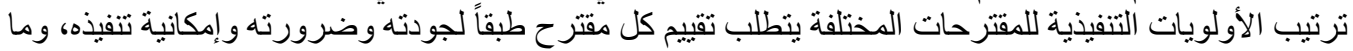

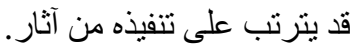

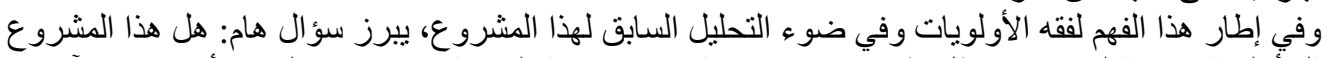

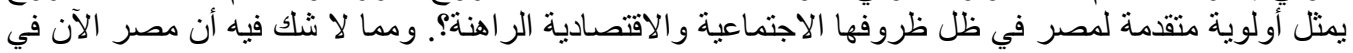

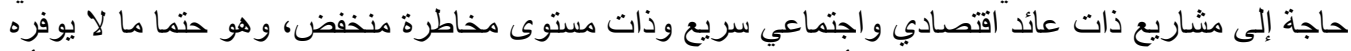

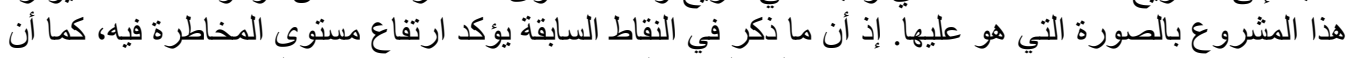

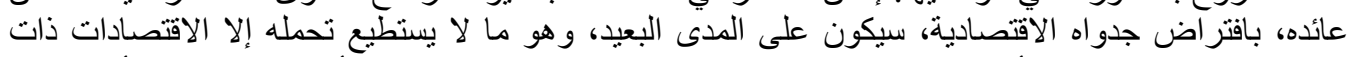

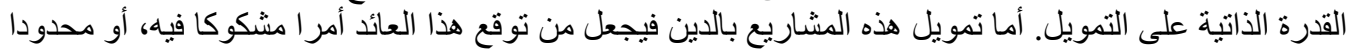

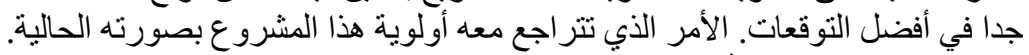

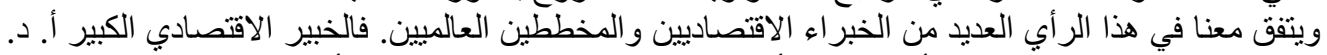

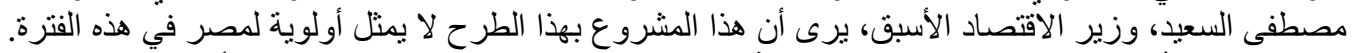

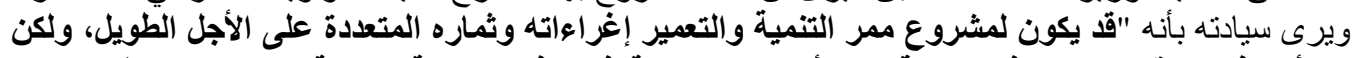

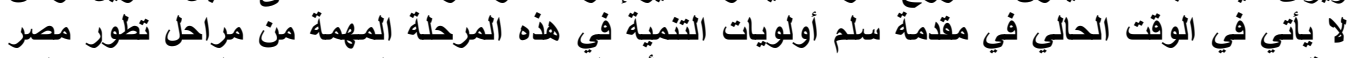

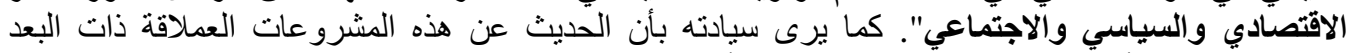

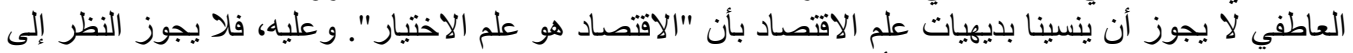

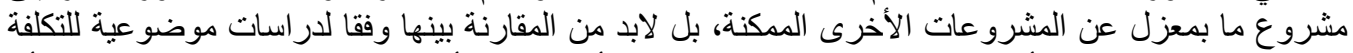

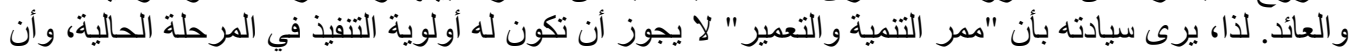

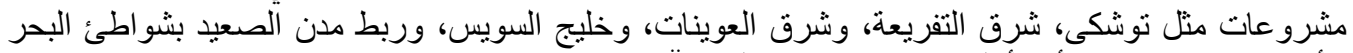

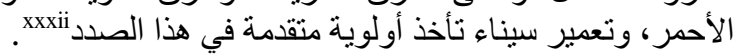

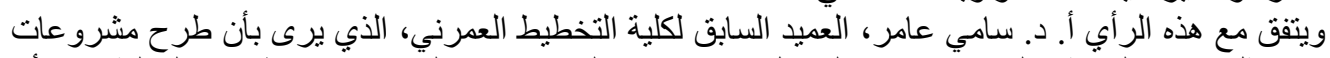

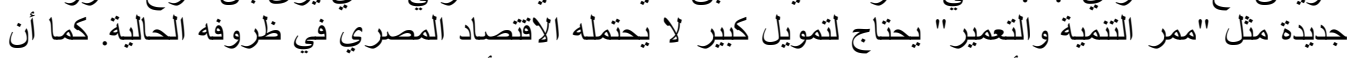

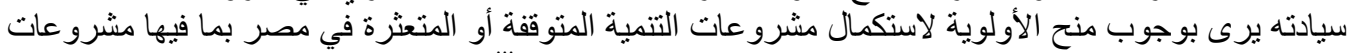

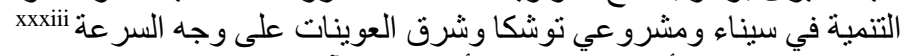

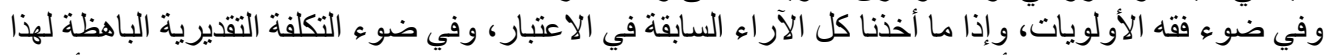

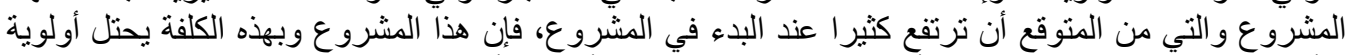

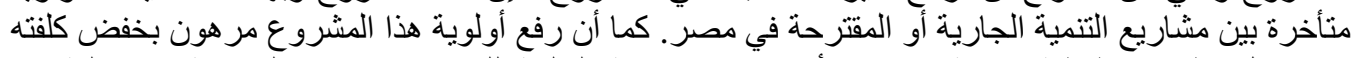

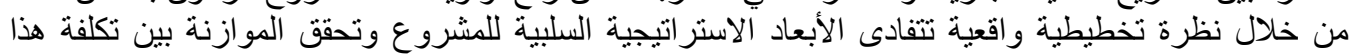

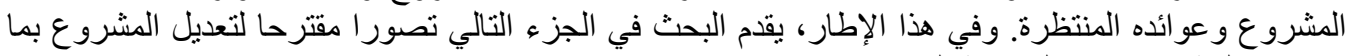
يتفادى غالبية الانتقادات الموجهة إليه.

\section{رابعاً: تصور مقترح لتطوير فكرة وعناصر المشروع}

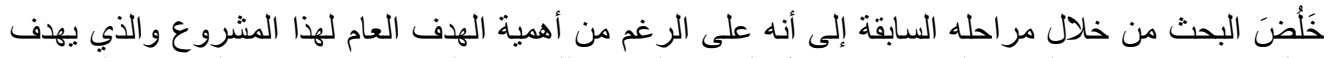

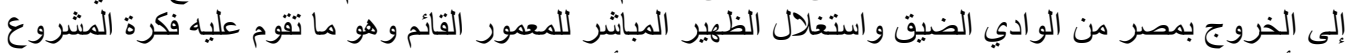

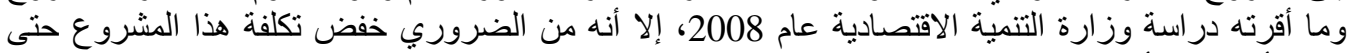

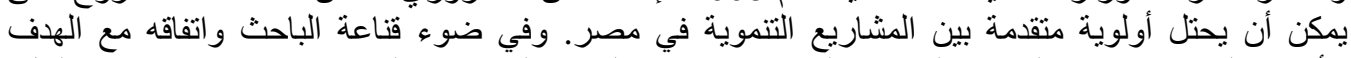

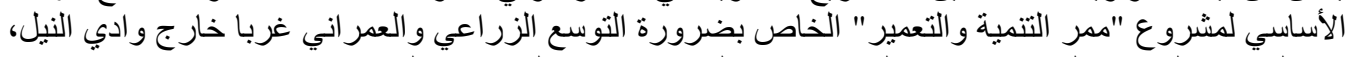

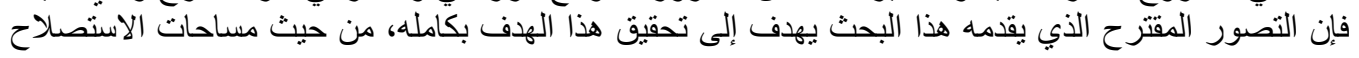


الزراعي والاستيعاب العمراني، بصورة رشيدة تقلل بشكل كبير من تكلفة هذا المشروع وبما يتفاى الإنتقادات

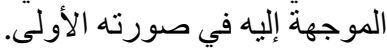

ـ الفكرة التخطيطية ومميز اتها:

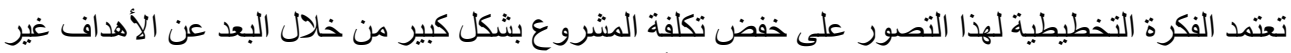

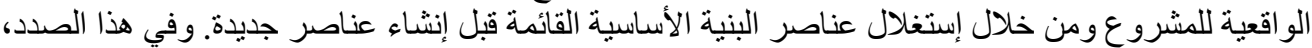

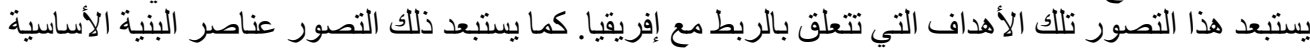

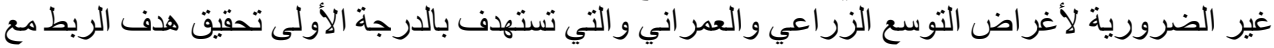

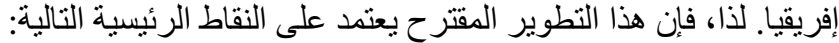

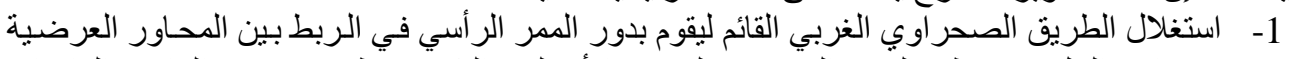

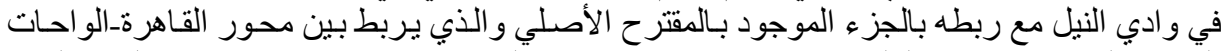

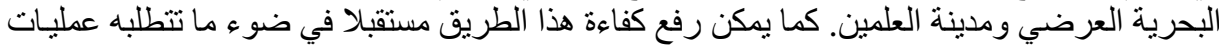
التنمية المستقبلية عليه.

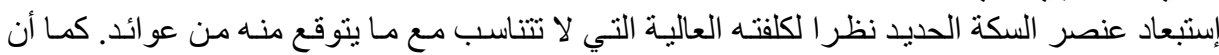

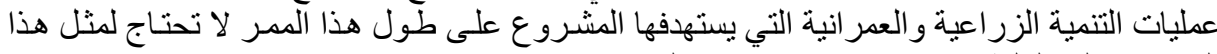

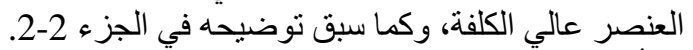

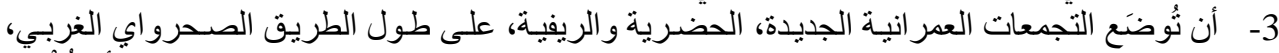

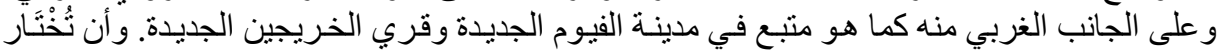

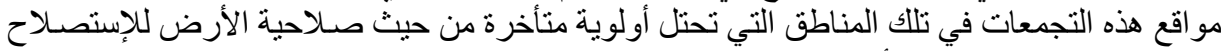

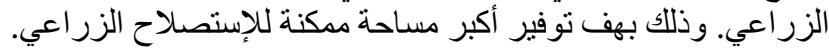

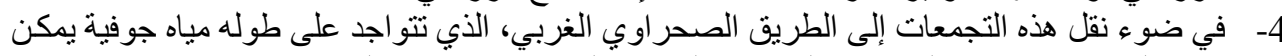

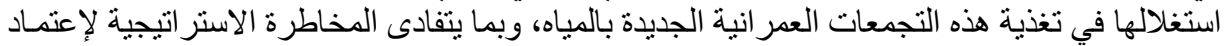

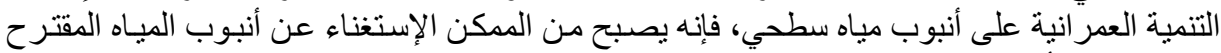

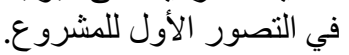
5- لكي يغطى هذا التطوير جميع أراضي الاستصلاح التي كان يستهدفها التصور الأول للمشروع، يقترح

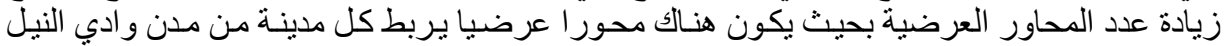

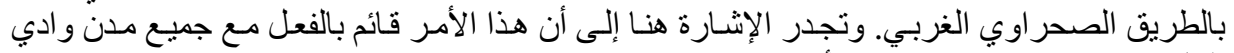

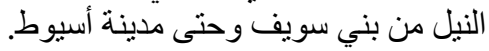

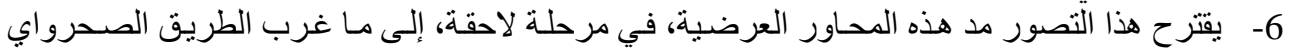

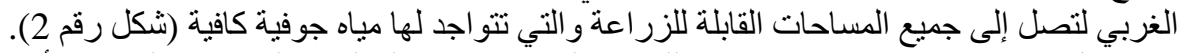

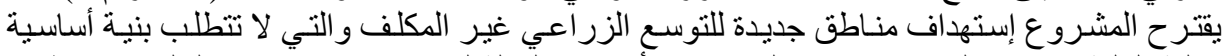

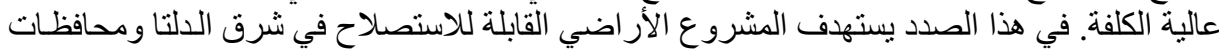

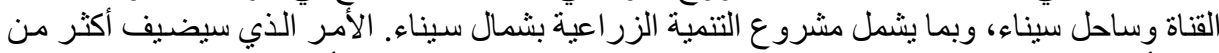

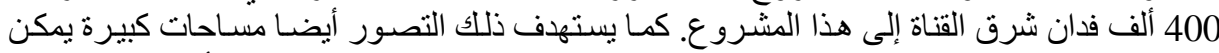

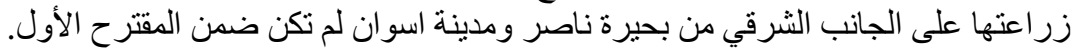

يوضح الشكل رقم 3 الفكرة العامة للتصور المقترح، والذي يقوم فيه الطريق الصحر اوي الغربي القائم بدور

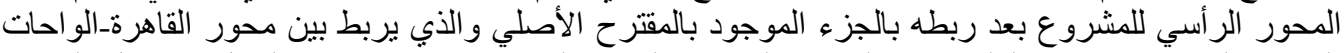

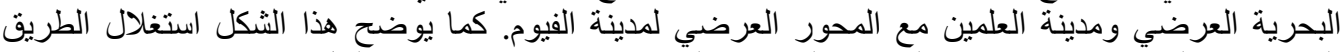

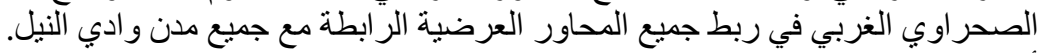

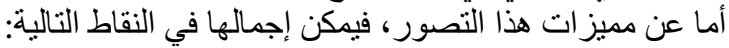

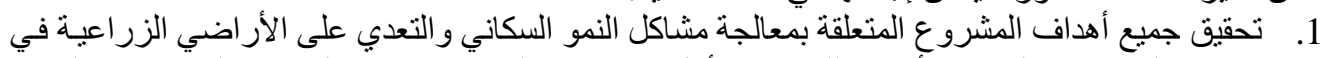

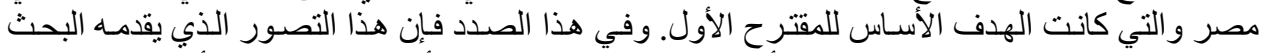

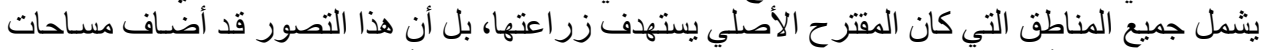

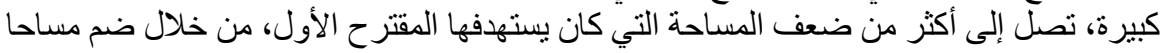


2. ت جديدة للتوسع الزر اعي في شرق الدلتا ومحافظـات القناة وسـاحل سيناء وكذلك منـاطق شرق أسوان وبحيرة السد.

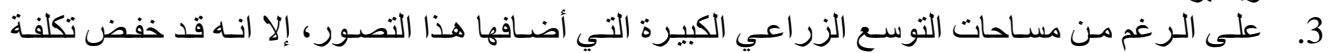

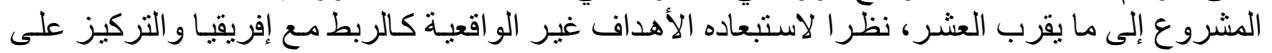

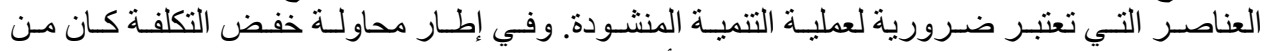

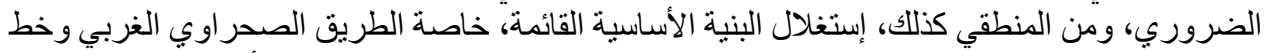

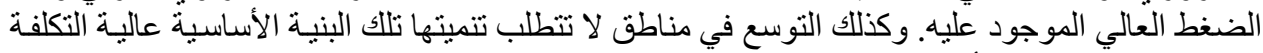
الموجودة في المقتر ح الأول. الموليه.

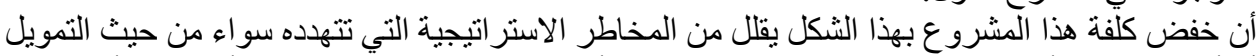

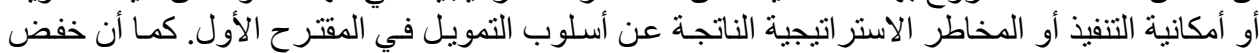

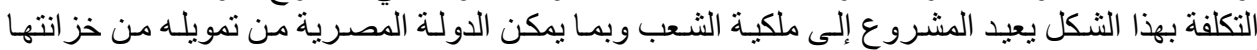

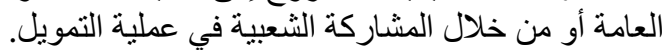

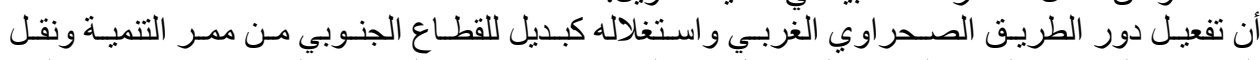

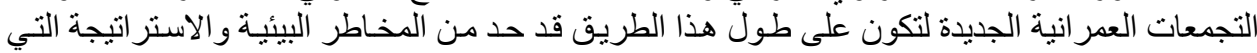

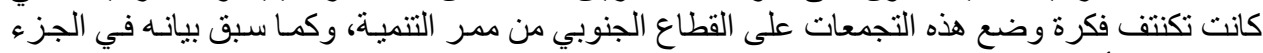

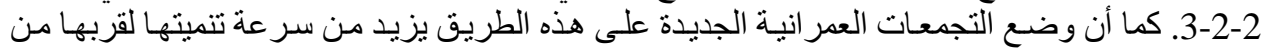

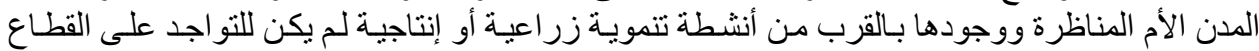

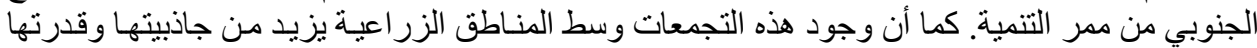

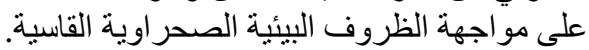

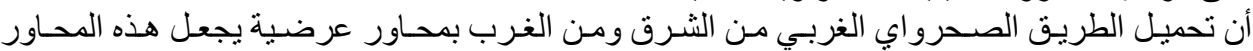

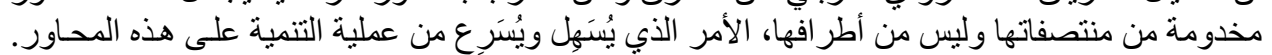

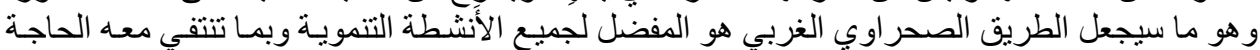

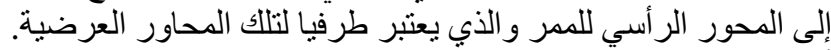

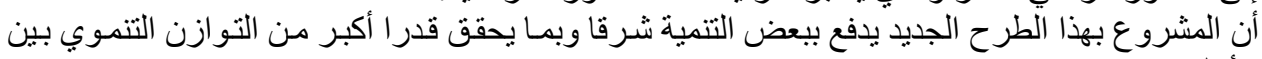
الأقاليم.

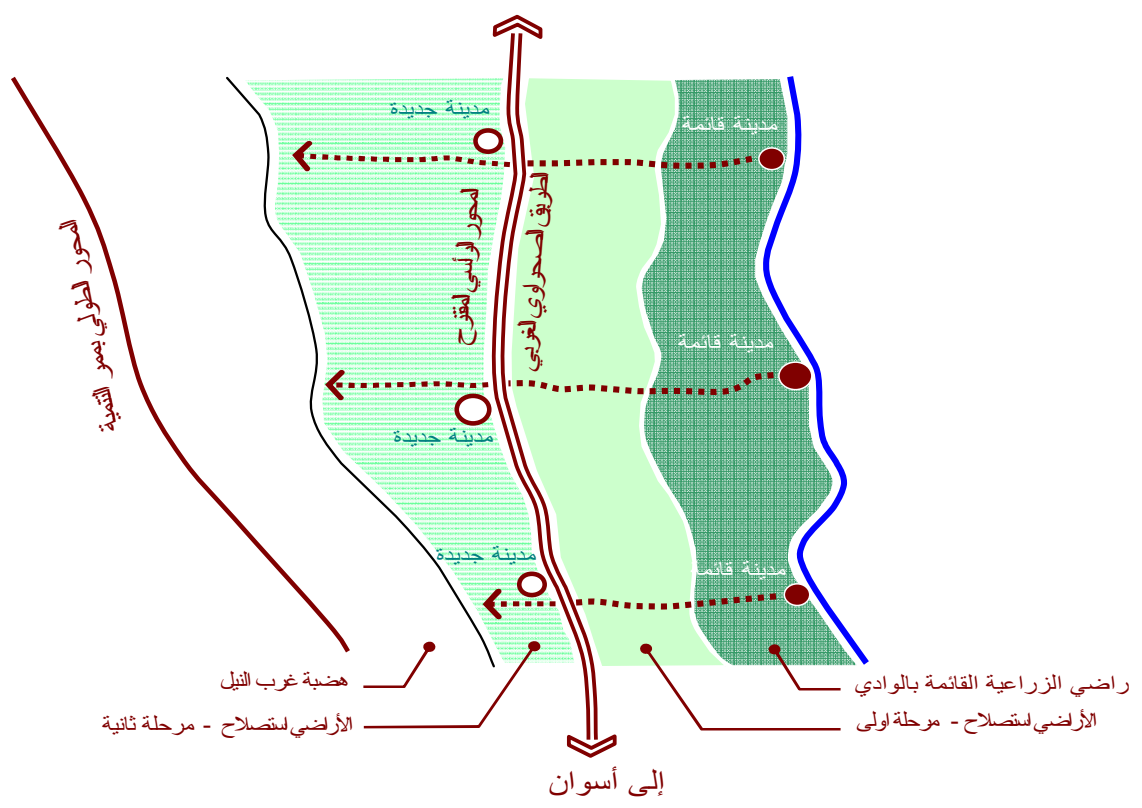

شكل رقم 2: التصور العام لربط المحاور العرضية لجميع مدن وادي النيل مع الطريق الصحر اوي الغربي وعمليات التوسع الزر اعي و العمر اني 


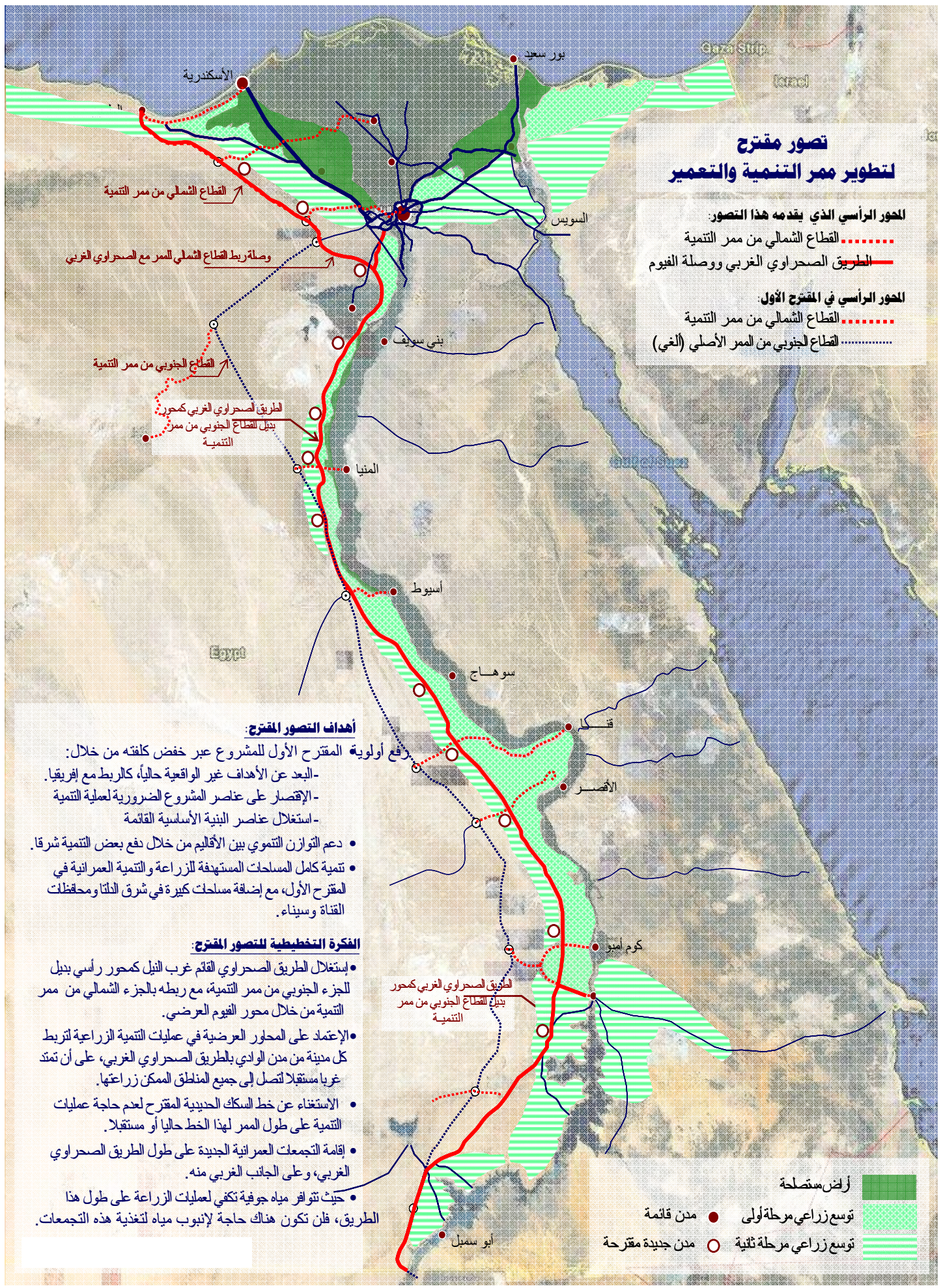

شكل رقم 3: الفكرة العامة للتصور المقترح - الطريق الصحر اور الغربي القائم كمحور راسي للمشروع 


\section{ـ سياسة التنمية Development Policy}

من حيث أسلوب وطريقة التنمية، فيقترح البحث إتباع سياسة التخطيط الثامل والتنفيذ التدريجي Comprehensive Planning \& Incremental Implementation المشروع، زر اعية كانت أم عمر انية أم خدمية.

\section{ـ التخطيط الثامل والتنفيذ المرحلي لتتمية المحاور العرضية}

بحيث يتم إعداد مخطط شامل لتنمية المحاور العرضية و المسافات البينية وامتداداتها المستقبلية غرباً، ومـا

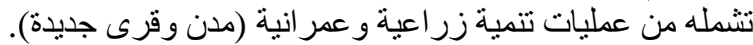

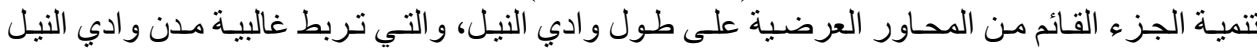

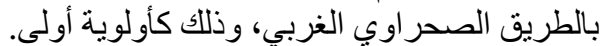

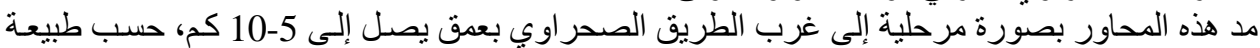

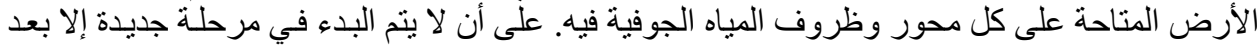
التأكد من تتمية ما لا يقل عن 50\% من الت أر اضي المرحلة السابقة.

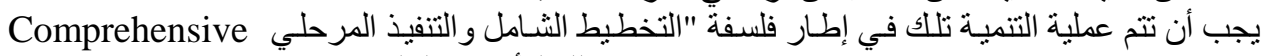
Planning \& Incremental Implementation

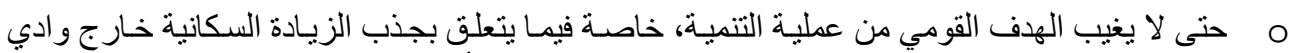

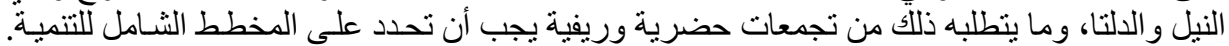

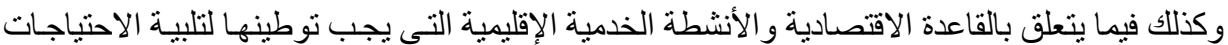

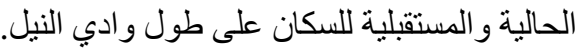
o

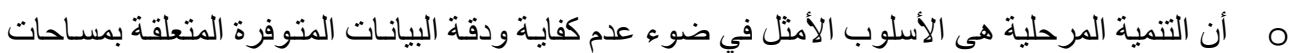

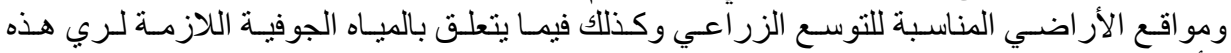
الأر اضي.

O أن ذللك يتلاءم مع الظروف الاقتصنادية للاولة.

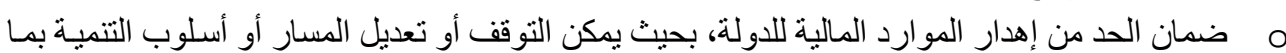

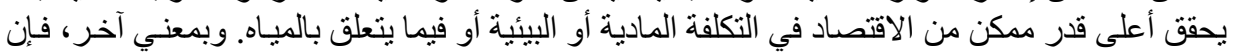

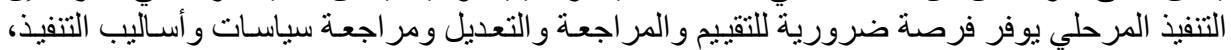
وبما يضمن الكفاءة الاقتصادية في تكلفة تنفيذ المرحلة اللاحقة والعائد المتوقع منها.

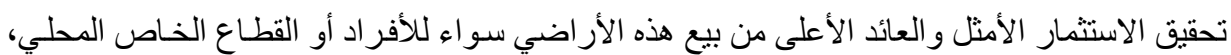

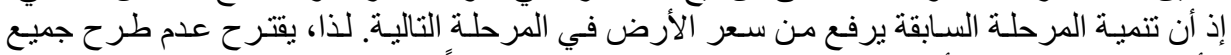

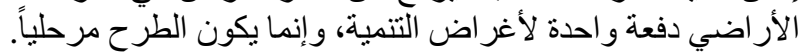

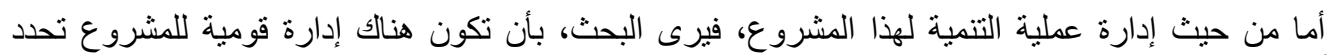

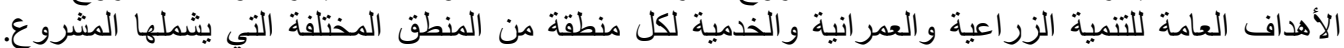

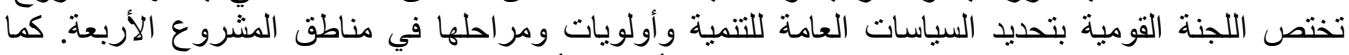

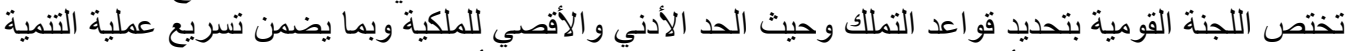

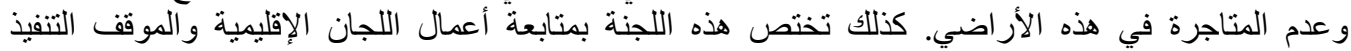
للمشرو عات.

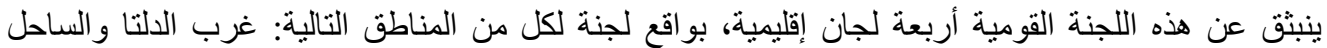

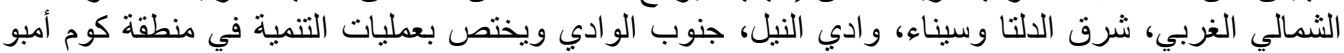

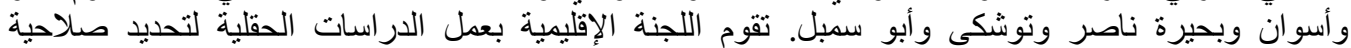

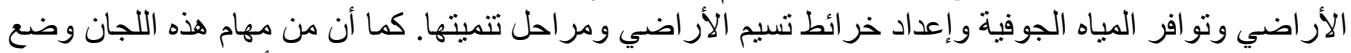

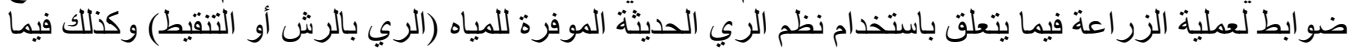

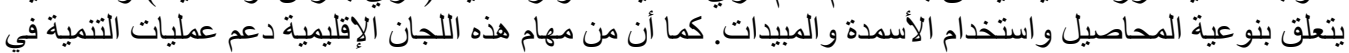


كل منطقة من حيث: أن تتم عمليات حفر الآبار وعمليات الاستصلاح ومد شبكات الري من خلال شركات معتمدة الإن الإنة

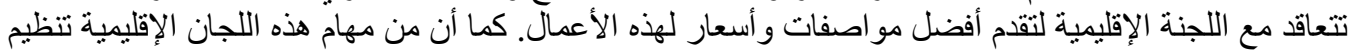

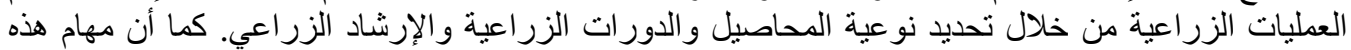

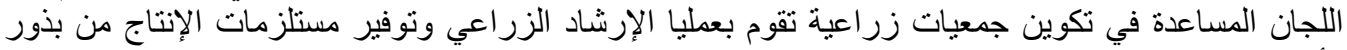

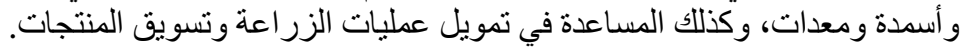

ـ أسلوب التمويل:

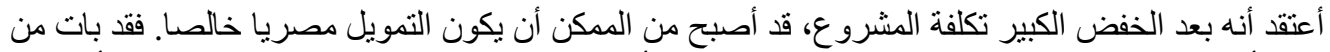

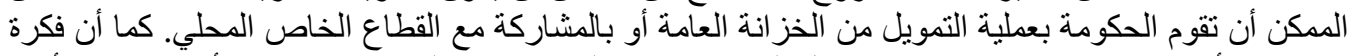

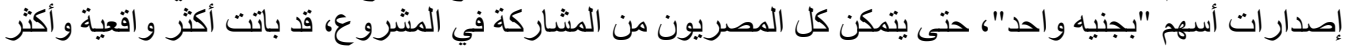

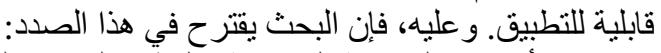

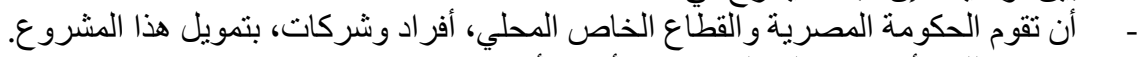

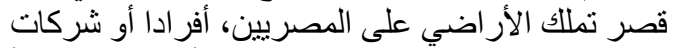

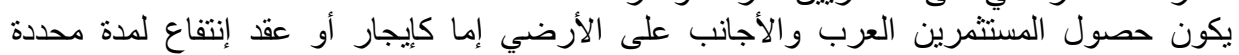

\section{و لاستعمال محدد. يشكل عائد بيع الأر اضي أو تأجير ها جز عا من تمويل عمليات التتمية في هذا المشروع. النتائج والثو تهيات:}

خَلُصنَ البحث من خلال مراحله المختلفة إلى أن هناك بعض الإنتقادات الجوهرية لمشروع "ممر التنمية

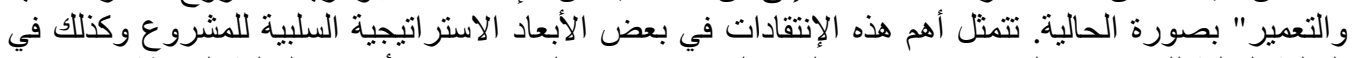

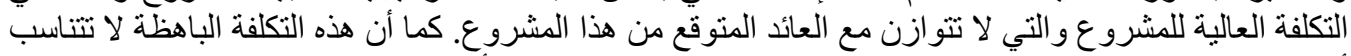

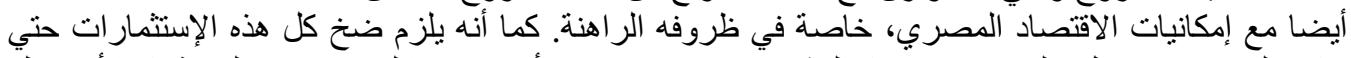

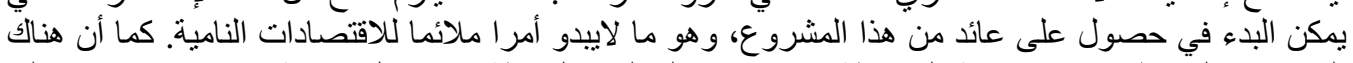

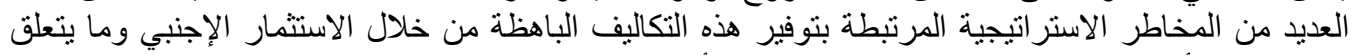

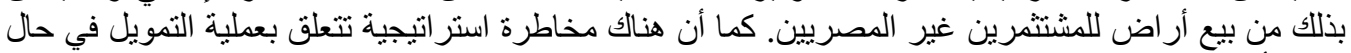

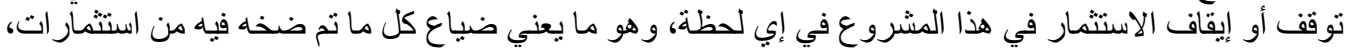

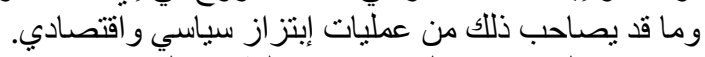

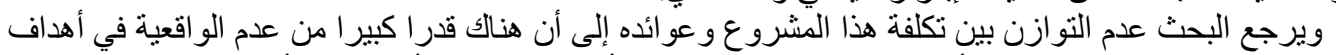

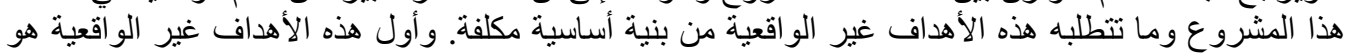

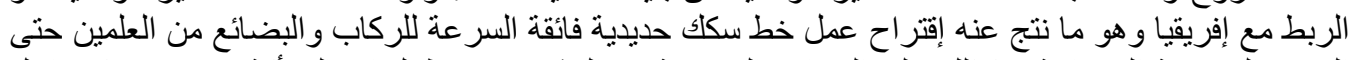

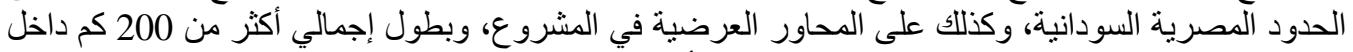

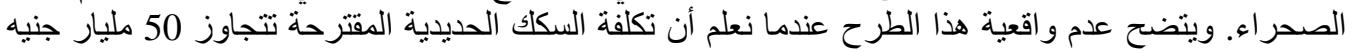

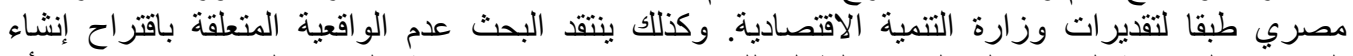

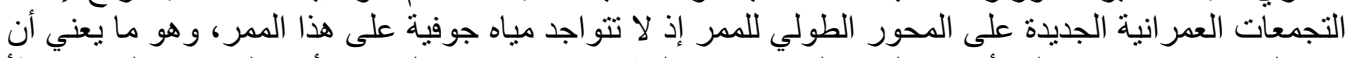

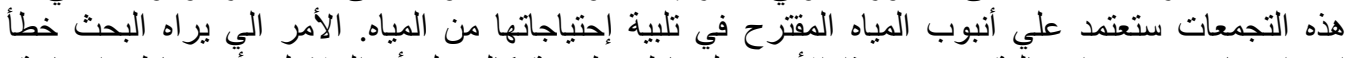

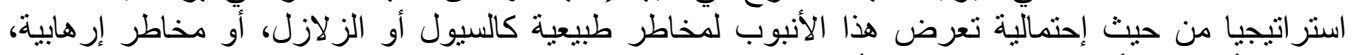

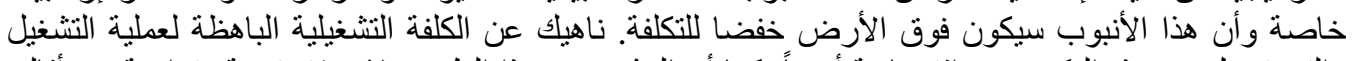

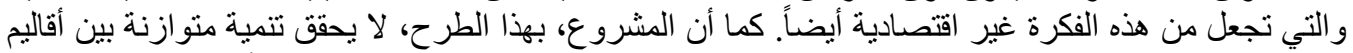

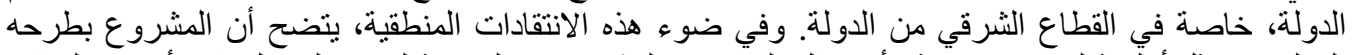

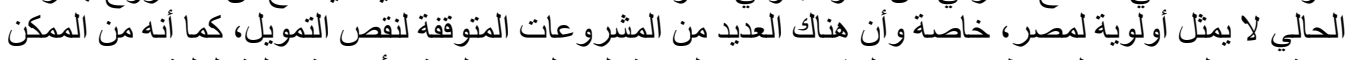

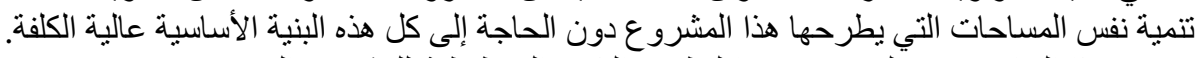

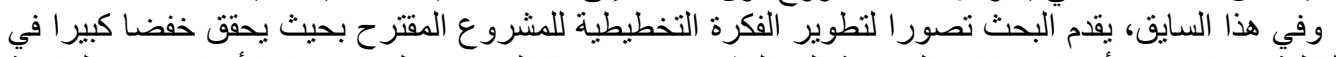

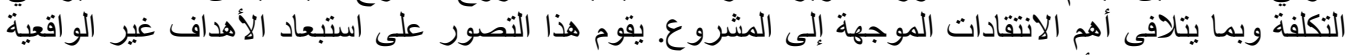

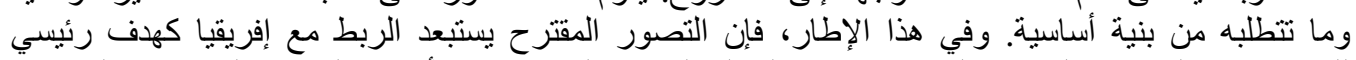

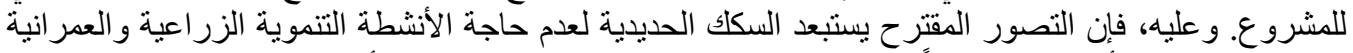

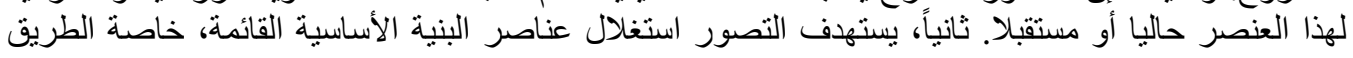




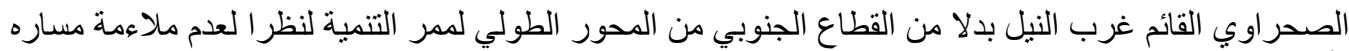

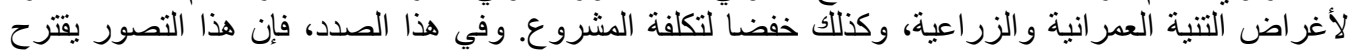

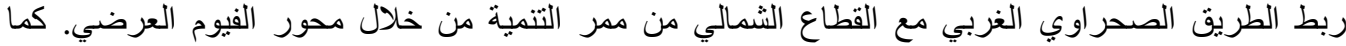

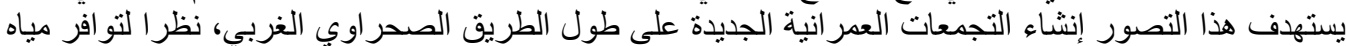

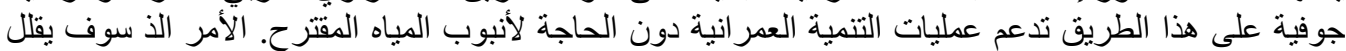

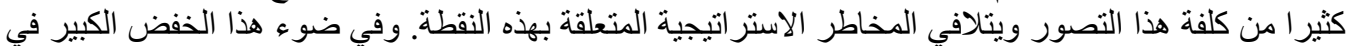

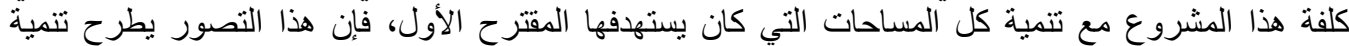

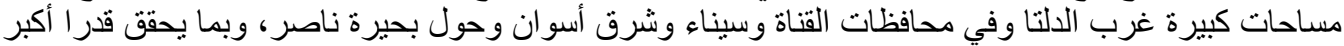
من التوازن التتموي بين الأقليم. خاصة وأن وأن تنمية هذه المساحات لا تتطلب بنية أساسية مكلفة، مقارنة بما هو

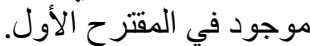

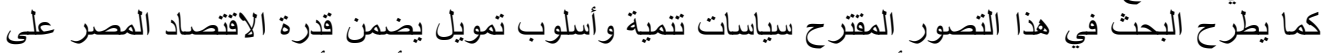

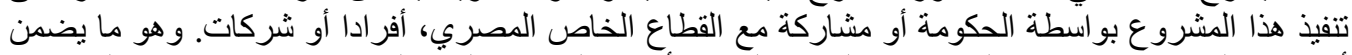

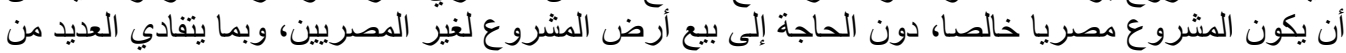
المخاطر الاستر اتيجية المتعلقة بعملية التمويل.

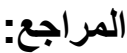

فاروق الباز، 2006. ندوة "ممر التنمية المصري ... حلم الباز المتجدد" تنظيم: جمعية حقوق المواطن بنقابة

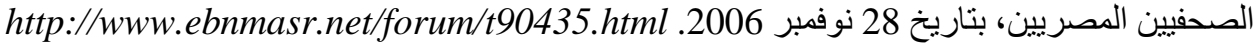

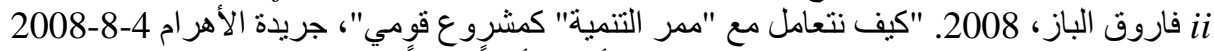

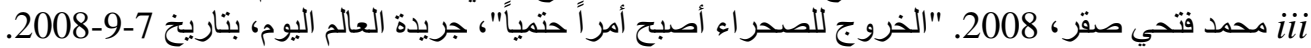

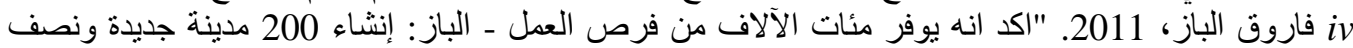

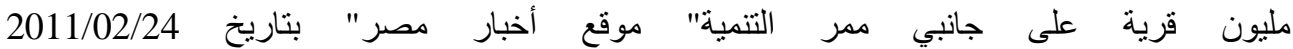
http://www.egynews.net/wps/portal/news? params=116645 v فاروق الباز، 2007. "ممر التتمية والتعمير وسيلة لتأمين مستقبل الاجيال الجديدة في مصر"، دار العين للنشر،

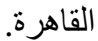

vi فاروق الباز ، 2006. "ممر التنمية والتعمير" ندوة نظمتها جمعية حقوق المواطن بنقابة الصحفيين المصربين

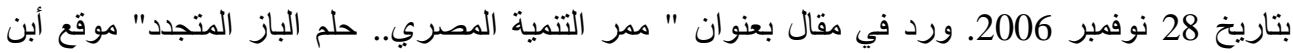

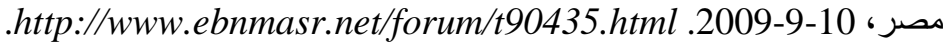
vii وز ارة التنمية الاقتصادية، 2008. "النتائج الأولية لدر اسات الجدوى الاقتصادية و الفنية لمشروع ممر التنمية"،

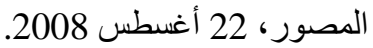
viii وزارة التنمية الاقتصادية، 22008، "النتائج الأولية لدراسات الجدوى الاقتصادية والفنية لمشروع ممر التتمية"، المصور، النية الافئ 22 أغسطس 2008.

ix فاروق الباز، 2011. " الباز بطالب بإنشاء شركة مساهمة لتمويل مشروعات التتمية وينفي ترشحه لرئاسة الإنية

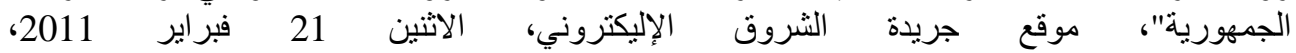
http://www.shorouknews.com/ContentData.aspx?id=394006 x فاروق الباز، 2011. لقاء تليفزيزني مع برنامج "العاثرة مساء" بتاريخ 11-04-2011. xi أحمد الجريسي والبيد، السيد الطر ابيلي، 2011.

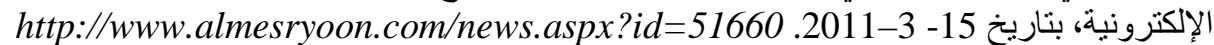

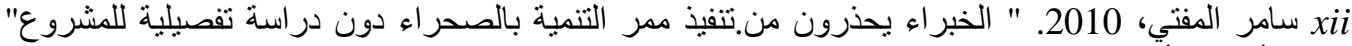
http://digital.ahram.org.eg/articles.aspx?Serial=180781 \&eid=885 الأهر ام الأليكتروني،

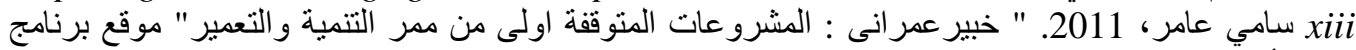
"أخبار مصر "،

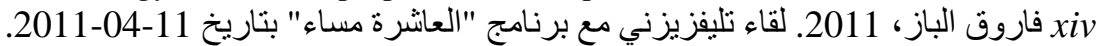


xv فاروق الباز، 2011. " الباز يطالب بإنشاء شركة مساهمة لتمويل مشروعات التتمية وينفي ترشحه لرئاسة الجمهورية"، http://www.shorouknews.com/ContentData.aspx?id=394006

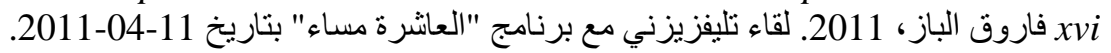

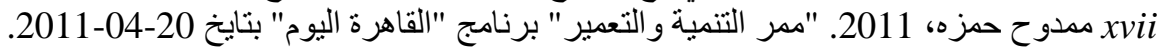
xviii مصطفى السعيد، 2011. " ممر التنمية و التعمير وأولويات التنمية"، جريدة التريخ الثروق، بتاريخ 5 مايو 2011 رix رشدي سعيد، 2006. نص خطاب موجه من أ. د. رشدي سعيد إلى الأستاذ سلامة أحمد سلامة المنشور

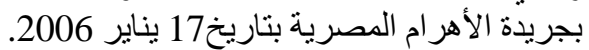

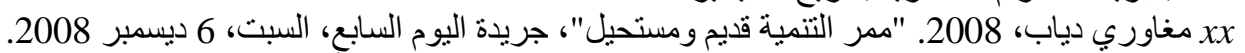

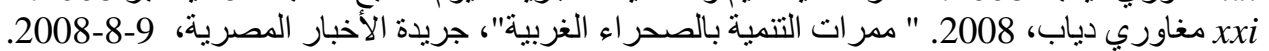

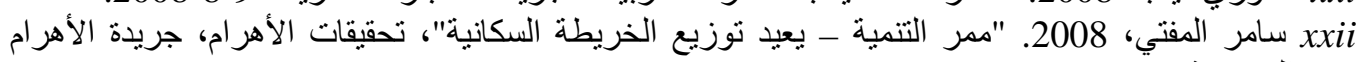

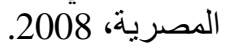

xxiii وز وارة الري والمي، 2008.

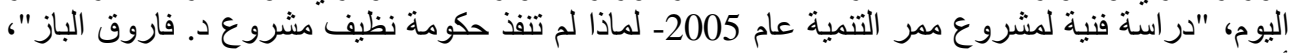
أخبار اليوم، 22/02/2011. vxiv وز ارة التنمية الاقتصادية، 2008. النتائج الأولية لدراسات الجدوى الاقتصادية والفنية لمشروع ممر التنمية، المصور ، 22 أغزارة الغنس الاقس 2008.

xxy فاروق الباز. 2011. "الباز : إنشاء 200 مدينة جديدة ونصف مليون قرية على جانبي ممر التنمية" موقع

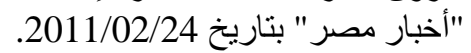

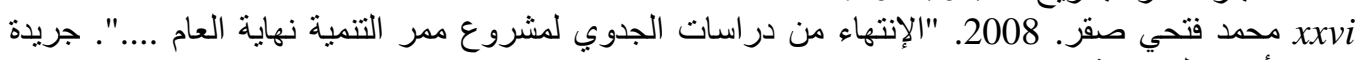

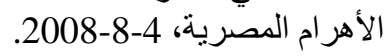

xxvii وزارة التنمية الاقتصادية، 2008. 2008. "النتائج الأولية لدراسات الجدوى الاقتصادية والفنية لمشروع ممر

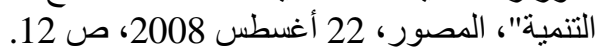

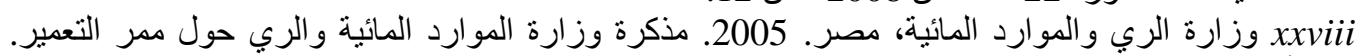

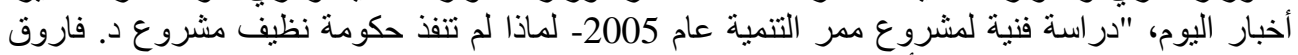

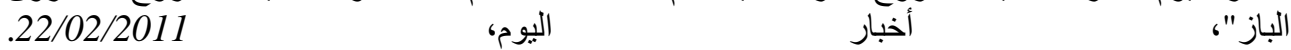

http://www.akhbarelyom.org.eg/elakhbar/detailze.asp?field=news\&id=29944 وزxix وزارة التنمية الاقتصادية، 2008. "النتائج الأولية لدراسات الجدوى الاقتصادية والفنية لمشروع مر

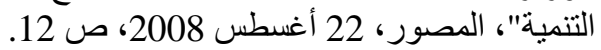

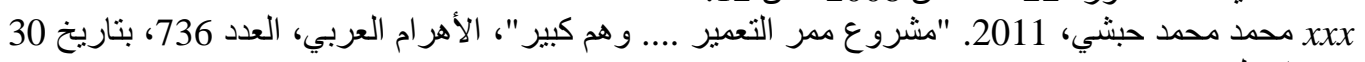

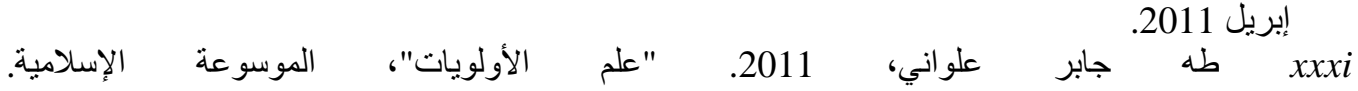
http://www.balagh.com/mosoa/feqh/u512by6v.htm xxxii مصطفى السعيد، 2011. " ممر التنمية والتعمير وأولويات التنمية"، جريدة الثروق، بتاريخ 5 مايو 2011 xxxiii سامي عامر، 2011. " خبير عمر 2011. "أخبار مصر "، "امر، 